\title{
Del subprefecto Teodomiro Gutiérrez al revolucionario Rumi Maqui Ccori Zoncco (mano de piedra corazón de oro). Cartas a Andrés A. Cáceres
}

\section{RESUMEN}

Sobre Teodomiro Gutiérrez ha quedado una estela de misterio. Fue un militar que tuvo simpatía con los reclamos de los indígenas y que se identificó con sus reclamos dirigiendo una rebelión. Algunos suponen que murió en algún enfrentamiento contra las fuerzas del orden; otros que luego del conflicto desapareció sin dejar rastro pero sí material para la leyenda. En este artículo trata de dilucidar algunos de estas interrogantes sobre la base de cartas inéditas del Archivo Andrés A. Cáceres de la Biblioteca Nacional del Perú.

Palabras Clave: Teodomiro Gutiérrez; Rumi Maki; rebelión indígena; correspondencia.

\section{From the sub-prefect Teodomiro Gutiérrez to the revolutionary Rumi Maqui Ccori Zoncco (stone hand, golden heart). Letters to Andres A. Caceres}

\begin{abstract}
A trail of mystery has remained about Teodomiro Gutiérrez. He was a military man who sympathetic to the claims leading a rebellion. Some suppose that he died in some confrontation against the forces of order; others that after the conflict disappeared without a trace but material for the legend. In this article the author tries to elucidate some these questions on the basis of unpublished letter from the Andrés A. Cáceres of the National Library of Peru.
\end{abstract}

Keywords: Teodomiro Gutiérrez; Rumi Maki; Indigenous rebellion; Correspondence. 
o que nos ha quedado de Teodomiro Gutiérrez es una estela de misterio rodeada de cierta mirada romántica plena de admiración. En efecto, no se sabe mucho de su biografía; cómo transcurrió su juventud, menos cuándo, cómo y dónde murió. Se conoce, sí, que fue un militar (llegó al grado sargento mayor) que tuvo simpatía con los reclamos de los indígenas, que fue destacado por el presidente Guillermo E. Billinghurst a Puno para analizar las causas de la sublevación indígena allí producida, que en esa misión terminó identificándose con los reclamos indígenas dirigiendo una rebelión y que luego de su apresamiento y fuga no volvió más. Algunos suponen que murió en algún enfrentamiento contra las fuerzas del orden; otros que luego del conflicto desapareció sin dejar rastro pero sí material para la leyenda. Por todo esto, a Teodomiro Gutiérrez lo rodea un aura de misterio y romanticismo, pero ¿cuál es la historia de este personaje elusivo surgido en los tiempos de la República de notables (18951919) peruana?

\section{Una figura histórica y mítica}

Desde el propio José Carlos Mariátegui, la figura de Teodomiro Gutiérrez (Rumi Maqui Ccori ZonccoMano de Piedra Corazón de Oro), ${ }^{1}$ es al mismo tiempo, un enigma y una exaltación romántica. En efecto, desde entonces, diversos estudiosos y testimonios orales han brindado información que permiten obtener una imagen más cabal del ser humano y rebelde social que fue este personaje. Luis Gallegos (1973), Antonio Rengifo (1977), Augusto Ramos Zambrano (1985), Alberto Flores Galindo (1987), Carlos Contreras y Jorge Bracamonte (1988), Carlos Arroyo Reyes (2005), entre otros, nos han proporcionado visiones generales y datos específicos que han enriquecido notablemente el conocimiento sobre este luchador social. El presente trabajo pretende sumarse a tal esfuerzo.

Utilizo fundamentalmente correspondencia privada, cartas que Gutiérrez escribió y remitió al general Andrés A. Cáceres, el héroe de la campaña de La Breña (1881-1883). En este caso, las cartas comple-

1 En adelante, para abreviar y facilitar la lectura, solo me referiré a Rumi Maki. mentan, y a veces profundizan, la información que se puede recabar mediante otro tipo de fuentes, como artículos periodísticos, documentos de propaganda, revistas, libros y otros. El presente es un estudio que, partiendo de información de fuentes primarias inéditas como son las cartas de Gutiérrez a Cáceres, incorporo fuentes secundarias aparecidas en diarios y revistas de la época así como bibliografía que han abordado en el tema que es preocupación central del presente texto. Así, es posible reconstruir la época y el momento preciso con la finalidad de ubicar a los personajes y las acciones que deciden tomar en un complejo histórico socialmente determinado.

Al permitir ingresar al mundo subjetivo del corresponsal (o corresponsales) se enriquece el análisis, y da sentido a decisiones que pueden no ser comprendidas a cabalidad desde una mirada ajena o externa. En el caso de Teodomiro Gutiérrez podemos ver — desde su constante comunicación epistolar con Cáceres-, cómo vive su permanente conflicto con los poderes locales (gamonales), su sensibilidad frente a la situación del indígena, su reclamo para que le devuelvan su grado militar, su admiración por el héroe, entre otros aspectos que nos ayudan a obtener una interpretación más completa del ser humano que existe detrás del mito. ${ }^{2}$

En el Archivo Andrés A. Cáceres que custodia la Biblioteca Nacional del Perú ${ }^{3}$ se encuentran 31 cartas que Gutiérrez le dirigió —entre 1903 y 1914 — al héroe de La Breña; además, hay una escrita al yerno de este, Carlos Porras, de 1903 (véase Anexo. no. 5), y otra dirigida a Nicolás de Piérola de 1896 (esta

2 Sobre la importancia de la correspondencia personal en el análisis social, puede consultarse, entre otros trabajos: Michael Löwy, Para una sociología de los intelectuales revolucionarios: la evolución politica de Lukács, 1909-1929, Siglo Veintiuno editores, México 1978; también Ricardo Melgar Bao, "El epistolario como vehículo de comunicación y cultura: México en las cartas de José Carlos Mariátegui”, Pacarina del Sur ańo 5, núm. 18, enero-marzo, 2014, www.pacarinadelsur.comindex.php?option=com_con tent\&view=article\&id $=914 \&$ catid $=46$. Complementariamente, se puede consultar el artículo de Osmar Gonzales Alvarado, "Epistolarios. Una mirada a correspondencias de intelectuales", http://www.librosperuanos.com/autores/articulo/00000002175/ Epistolarios.-Una-mirada-a-correspondencias-de-intelectuales

3 Los documentos que componen el Archivo Andrés A. Cáceres llegan como donación a la Biblioteca Nacional del Perú en el año 1950 gracias a la gestión de la hija del héroe, dońa Zoila Cáceres, cuando era director de dicha institución el matemático Cristóbal de Losada y Puga. Al respecto, se pueden conocer más detalles gracias al artículo de Evelyn Toribio Córdova, "El Archivo Andrés Avelino Cáceres en la Biblioteca Nacional del Perú”, Fénix núm. 46, 2017. 
pertenece al Archivo Nicolás de Piérola, también de la Biblioteca Nacional del Perú; véase Anexo no. 4).4 La primera misiva de Gutiérrez a Cáceres fue enviada desde Huánuco en 1903 y la última desde Lima en 1914. El tono siempre es de admiración y cariño por parte del sargento mayor para quien fue su jefe durante el conflicto armado contra Chile ("Mi tan querido y respetado general", "Mi tan apreciado y distinguido jefe", "Mi tan querido general y amigo"), y a él recurría en los momentos de mayores dificultades: “... ¿á quien debo ocurrir sino a Ud. mi antiguo jefe en cuyas charreteras palpita el esfuerzo y la abnegación de todos y cada uno de los de la breña, legión modelo de sufrimiento, de patriotismo de valor?" (Lima, a 31 de agosto de 1911).

Según Luis Bustamante (1987), la carrera militar de Gutiérrez pasó por los siguientes momentos: participó en la defensa de Lima en 1881, el mismo año en el que se produjo la invasión chilena a LA CAPITAL y colaboró con el gobierno de Francisco García Calderón, para luego internarse en la Sierra Central E incorporarse a las tropas de Cáceres, peleando en las batallas de Pucará y Marcavalle. Una vez concluida la Guerra con Chile, Gutiérrez ingresa al Regimiento de Gendarmes de Lima; posteriormente, entre 1893 y 1894, ingresa a la II comisaría de Lima, luego se integraría a los carabineros de Cañete.

La carrera de Gutiérrez se vería interrumpida por el estallido de la guerra civil en 1895 entre el gobierno de Cáceres y la Coalición Nacional (de demócratas y civilistas), que terminaría destituyendo al héroe militar.

Luego de su derrota, Cáceres marcharía al exilio, junto a gran parte de sus oficiales, salvo aquellos que se acogieron a la amnistía de 1895. Acompañándolo en su desventura, Gutiérrez también se exiliaría y engrosaría el "cuadro de indefinidos", es decir, "sin destino", sin puesto en la dependencia militar. ${ }^{5}$ En

4 Complementariamente, transcribimos dos documentos de Teodomiro Gutiérrez (véanse anexos no. 2 y 3) e incluimos algunas imágenes que nos ayudan a perfilar mejor a nuestro personaje. Es de advertir que la transcripción es textual.

5 "Las leyes del 29 de octubre de 1845 y del 7 de enero de 1848 establecieron que a todos los militares sin colocación en ningún ramo del Ejército se les concedería la condición de licencia indefinida, es decir, que se les retiraría del servicio activo indefinidamente hasta que se produjeran vacantes dentro de la graduación militar. Dado que se licenciaba a los oficiales sin darlos de baja, estos seguían siendo considerados dentro del escalafón, mantenían sus grados de oficiales, el fuero militar y sus derechos a pensiones”, según informa Jorge tanto, Nicolás de Piérola, durante su segundo gobierno (1896-1899), contrataba a una misión militar francesa para reformar el ejército, lo que significaría "el comienzo del fin del viejo militarismo" (Zapata, 2015).

La carrera en el ejército de Gutiérrez se puede registrar de la siguiente manera estableciendo una cronología: no aparece en el Escalafón general del Ejército y la Armada de 1888, pero sí en el del año siguiente con fecha de ingreso el 24 de junio de 1899 (Escalafón general del Ejército y la Armada, 1899), ostenta el grado de capitán hasta el año 1904 ( Ministerio de Guerra y Marina, 1904, pág. 17); en 1906 ya está registrado como sargento mayor (Ministerio de Guerra y Marina, 1907, pág. 10); igualmente en 1907 (Escalafón general del Ejército. Publicación Oficial, 1908, pág. 10) y 1909 (Ministerio de Guerra y Marina, 1909, pág. 9). En 1910 aparece como retirado de guerra con fecha de cédula del 9 de noviembre de 1908, con 14 años, 5 meses y 20 días de servicio, con una pensión de 6 Lp. 7 soles y 66 centavos (Ministerio de Guerra y Marina , 1910, pág. 16), constando Apurímac como la tesorería que verifica el pago y con una anotación que dice: "Jefe Prv. Canta". Más adelante figura como retirado por Cusco y en Anotaciones aparece como jefe provincial de Canas. En el Escalafón de 1913 aparece como sargento mayor de caballería (Estado Mayor General del Ejército , 1913), igual que en los de 1914 y 1915 (Estado Mayor General del Ejército, 1914) (Escalafones de actividad, disponibilidad y retiro, 1915, pág. 4). En el de 1916 figura como mayor (Escalafones de actividad, disponibilidad y retiro, 1916). ${ }^{6}$

Basadre. Ver: David Víctor Velásquez Silva, "La reforma militar y el gobierno de Nicolás de Piérola. El Ejército moderno y la construcción del Estado peruano", Tesis para optar el grado académico de magíster en Historia Universidad Nacional Mayor de San Marcos, Lima, 2013, págs. 47-48.

Complementariamente, Velásquez Silva también indica que: "A los oficiales caceristas se les empezó a llamar los 'caídos', mientras que a Cáceres se le dio el epíteto del 'nefando'. Existen testimonios que luego de la firma del armisticio que puso fin a la guerra civil, algunos jefes caceristas, reconociendo su derrota, solicitaron su pase a la condición de indefinidos, sin embargo, otros fueron derivados a esa condición, tanto durante la corta administración de la Junta de Gobierno de 1895, como en los primeros ańos del gobierno pierolista” (pág. 141).

6 Es necesario anotar que esta clasificación se realizó el 1 de abril, fecha importante, pues Gutiérrez sería apresado en el mes siguiente en Arequipa. 
Paralelamente a su vocación militar, Gutiérrez desarrollaría un fuerte compromiso con la política expresado en los diferentes cargos que asumió en tanto funcionario político. Por esta razón, Ramos Zambrano acierta en caracterizarlo como "un militar político" (2011). ${ }^{7}$

Por otra parte, una rápida ojeada a la distribución geográfica de las 31 cartas nos indica que once fueron remitidas desde Huánuco, dos desde Canta, una desde el Callao, doce desde Juli, dos desde Puno, dos desde Lima y una desde Ilave (véase Anexo no. 1). No hay respuestas de Cáceres, salvo dos anotaciones a mano que no llevan firma y que con toda seguridad pertenecen al héroe.

Gracias a esta correspondencia nos enteramos que Gutiérrez fue subprefecto en Huánuco, Canta y Chucuito. Desde su propia escritura también descubrimos algunos datos de su enigmática biografía. Antes de ingresar al análisis de las cartas propiamente, repasemos la breve biografía (probablemente la primera que se escribiera sobre nuestro personaje) que apareció en el número 3 de la revista El Indio, que dirigía el defensor de la causa indígena, Santiago Giraldo, y en la que denunciaba el cambio de Gutiérrez de la subprefectura de Chucuito para poner en su reemplazo al coronel José M. Vivanco:

Datos biográficos del subprefecto Gutiérrez Nació en el Cerro de Pasco el 25 de Julio de 1861: sus padres fueron el Dr. Julián R. Gutiérrez y la señora Beatriz Cuevas hija de un abogado argentino: el doctor Gutiérrez fue profesor de matemáticas de San Carlos, escribió varios folletos sobre la trisección del ángulo y teoría de las mareas: su tío don Mariano Dámaso Beraún célebre matemático fue rector de San Carlos.

Gutiérrez se dedicó a la carrera militar y su foja de servicios es importante: después de 1895 ha estado contraído al trabajo de minas y desde Enero de 1903 ha desempeñado las subprefecturas de Huánuco, Chachapoyas, Canta y Chucuito.

Acerca de su carácter moral, basta leer, el siguiente acápite de una carta del estadista Sr. Candamo: ${ }^{8}$

7 Consúltese la interesante entrevista a Augusto Ramos Zambrano por Mario Mayhua Quispe, "Necesitamos otro Rumi Maqui" publicada en: http://www.losandes.com.pe/Sociedad/20110313/47330.html

8 Manuel Candamo fue Presidente del Perú entre 1903 y 1904. Una muy buena biografía sobre este personaje ejemplar se puede encontrar en José Agustín de la Puente Candamo y José de la Puente Brunke (editores), El Perú desde la intimidad. Epistolario de Manuel
Tengo acerca de las condiciones que U. reúne para el desempeńo de los cargos políticos el mejor concepto, y es por esto que le propongo ahora nombrarlo Subprefecto de la Provincia de Chucuito, circunscripción territorial a la que doy la mayor importancia y que considero campo muy apropósito para que Ud. desarrolle en el las facultades que le distinguen. Ruégole conteste a la mayor brevedad, con entera franqueza si este cargo le conviene, para según eso ordenar su inmediata traslación, $\mathrm{Su}$ afectísimo amigo y S.S.- Manuel Candamo. ${ }^{9}$

Como se puede observar, se menciona que Gutiérrez fue subprefecto de Huánuco, Canta y Chucuito, lo que ya nos enteramos. Pero la nota agrega un dato más: que Gutiérrez también fue subprefecto de Chachapoyas, información que no hemos podido corroborar. Si bien en su correspondencia se observa un vacío de fechas entre junio y agosto de 1903, nada hace suponer que Gutiérrez haya sido trasladado a Chachapoyas, ciudad que no aparece mencionada en ningún momento de su extensa correspondencia con el héroe militar.

Otra sorpresa que guarda este paquete de cartas es que Gutiérrez era un convencido militante del Partido Constitucional fundado por Cáceres el 26 de julio de 1884 (El Comercio, 1884). ${ }^{10}$ Su lealtad para con el héroe de La Breña inició en el tiempo de la misma guerra contra Chile en la campańa que hizo célebre a El Brujo de los Andes, en la que se caracterizó — según se colige de sus propias palabras— por su compromiso por el deber: "Nadie mejor que Ud., mi General, sabe como he cumplido mi deber durante la guerra con Chile y las intestinas que han surgido después y en las que he tomado parte a sus órdenes y sin que jamás haya merecido la nota de cobarde. Cuando llegue aquí el momento cumpliré mi deber como lo he cumplido en todas partes" (Huánuco, 29 de abril de 1903). Desde entonces, es muy probable que Gutiérrez observara de cerca la vida miserable de los indios y admirara la defensa que de ellos hiciera

Candamo (1873-1904), Pontificia Universidad Católica del Perú, Lima, 2008.

9 "A última hora sabemos que el Subprefecto de Chucuito Comandante Gutiérrez ha sido separado, y reemplazado por el Crnl. José M. Vivanco", El Indio. Defensor de los intereses sociales de la raza indígena Año I, núm. 3, Lima, 27 de agosto de 1904, pág. 5

10 Para un análisis del Partido Constitucional véase: Iván E. Millones Marínez, "Los caceristas de la República Aristocrática: composición social, intereses y principios del Partido Constitucional (18951919)", Histórica Vol. XXVIII, núm. 2, 2004 
Cáceres; ambos hechos marcarían la vida y las ideas posteriores de Gutiérrez.

Durante el tiempo que Cáceres fue Presidente del Perú (1886-1890 y 1894-1895), Gutiérrez fue su leal secretario, y lo acompañó hasta que fue derrotado por la Coalición Nacional dirigida por Nicolás de Piérola luego de la guerra civil de 1895. Entonces, Cáceres se vio obligado a salir del país, hacia Argentina. Al parecer, igual camino siguió Gutiérrez. Al respecto, existe una carta que ratifica que se exilió en el mencionado país.

En efecto, con fecha Buenos Aires, 22 de mayo de 1896, Gutiérrez — que firma como sargento mayor del ejército- se dirige a Nicolás de Piérola, entonces presidente del Perú, para exponerle su opinión con respecto del movimiento separatista que había surgido en Iquitos. Señala que se encuentra "Fuerte y dolorosamente impresionado por la noticia" y que está convencido que detrás de estos movimientos está el gobierno de Chile, que "es el alma de las intrigas y maquinaciones que han producido la Revolución de Iquitos y que todos los elementos que recibe esta de casas francesas y alemanas del Brasil proceden de nuestro infame enemigo". Le aconseja que utilice la astucia por sobre la fuerza y le expone un plan para abatir la rebelión. Prosigue que es hora de la unidad "olvidando las rencillas partidaristas e invocando el sagrado nombre de la Patria deben secundar y robustecer la acción de V.E. para evitar a todo trance y por todos los medios el desmembramiento del territorio nacional". Al finalizar es más enfático aún: "Tengo ardientes deseos de estar al lado de V.E. y no marcho a esa inmediatamente por parecer de recursos si V.E. tuviera a bien le estimaría se dignase ordenar al Sr. Ministro la Rosas, por cuyo conducto recibirá V.E. la presente, que me proporcionare pasaje con cargo de reintegrar su valor en esa capital, en donde tendría el gusto de cumplir extrictamente sus órdenes".

No deja de llamar la atención el tono de la carta, especialmente tomando en consideración que Gutiérrez era un convencido militante del constitucionalismo, que combatió a la Coalición Nacional y que siempre expuso su convicción anti-pierolista. Sin embargo, notamos en las líneas transcritas que, en privilegio de la unidad nacional, no tiene dudas en ponerse al servicio de El Califa. No disponemos de más información, esperemos que en el futuro surjan más documentos y evidencias que nos permitan obtener una visión más amplia sobre este tema.

\section{De regreso al Perú y los cargos que asume}

En 1903, Manuel Candamo gana las elecciones presidenciales encabezando una alianza civil-constitucionalista. Cáceres y Gutiérrez, entre otros caceristas, pueden regresar al país y reintegrarse a la vida pública. Ese mismo año, por decisión del propio Candamo, y bajo auspicio de Cáceres, asume la subprefectura de Huánuco. Esta ciudad no era desconocida para Gutiérrez, pues como le escribe a Cáceres, ahí vivió años de su infancia:

Mi situación en este lugar es del todo excepcional respecto de cualquiera otra persona que hubiera sido nombrado para desempeñar este puesto. La circunstancia de haber crecido y sido educado aquí, de tener muchos parientes y amigos de colegio que hoy ocupan los más elevados puestos, de conservar todos el más grato recuerdo de mi Sr. padre que educó en dos épocas diferentes a la juventud huanuqueña, de haber sido mi madre nacida en esta ciudad y otras circunstancias mas me colocan en una condición favorable (Huánuco, 4 de febrero 1903).

En esas favorables condiciones, Gutiérrez cumple con una doble labor en Huánuco: la del ejercicio propiamente del puesto de subprefecto y la de organizar el Partido Constitucional. Sobre ambos ejes girarán sus cartas de febrero a mayo de 1903.

\section{Subprefecto de Huánuco: regreso a la ciudad de los primeros ańos}

A lo largo de nueve cartas, Gutiérrez da cuenta a Cáceres de los obstáculos que le van poniendo los poderes locales (representados por Augusto Durand, Teobaldo Pinzás y Ortega), que son los mismos que sojuzgan al indio y que se opondrían al constitucionalismo. (En ese sentido, Gutiérrez le advierte a Cáceres que le han engañado diciéndole que el partido está organizado). El enfrentamiento de Gutiérrez contra los poderes locales contra el gamonalismo es duro y definitivo. 
En la segunda carta (Huánuco, 19 de febrero de 1903), Gutiérrez informa que ha establecido una junta directiva en Huánuco presidida por Manuel Eustaquio Robles desaforando así a Pinzás, quien, según el propio Gutiérrez, no gozaba de ninguna simpatía, además de que es aliado de Juan Durand, perdiendo todo prestigio "si alguna vez lo tuvo" entre los constitucionalistas. $\mathrm{Al}$ mismo tiempo, pide que se envíe la publicación El Constitucional, unos 10 o 20 ejemplares, puesto que no se le conoce en Huánuco.

Inmediatamente después, Gutiérrez realiza un balance de las autoridades, proponiendo separar a algunos de ellos, y se compromete a cambiarlos por "gente buena y de confianza". Le sugiere a Cáceres que hable con Candamo y coordine las modificaciones. Insiste en señalar que no hay partido organizado, salvo, en alguna medida, el Civil, que está en negociaciones con el Liberal. En ello tiene que ver Durand y Pinzás, cuyas revoluciones solo son para defender puestos y conveniencias propios, sentencia Gutiérrez.

Por esa fecha, apareció en la publicación El Huallaga una nota de Nemecio A. Ráez — presidente de la Junta Departamental de Huánuco-, agradeciendo a Gutiérrez por una donación en efectivo que hizo a dicha Junta para la realización de una obra sumamente importante, el camino a Mayro. El texto es el siguiente:

Febrero 27 de 1903

Señor Teodomiro A. Gutiérrez.

\section{Ciudad.}

Puesto en conocimiento de la Junta de mi presidencia, en sesión de ayer, el contenido de la estimable carta de U. fechada el 25 del que cursa, contribuyendo con la suma de CIEN SOLES, para la apertura del camino al Mayro, cábeme la satisfacción de manifestarle, por acuerdo de dicha Junta, el agradecimiento de la Comisión, por su tan generoso obsequio, destinado á una obra de gran importancia para el Departamento.

Así mismo hago presente á U. la satisfacción con que han mirado los miembros de la Junta, su noble procedimiento, exitando el entusiasmo y patriotismo de todas las personas de esta Provincia, para que contribuyan á hacer práctico tan bello ideal'. Puede U. hacer entrega de la cantidad, que tan bondadosamente cede á favor de la Junta, en la Tesorería de la misma, que corre a cargo del Sr. Victorio Repetto.
Cúmpleme con tal motivo; ofrecerle las seguridades de mi más alta estimación y particular aprecio. Dios gue á Ud.

Nemecio A. Ráez. (Ráez, 1903).

En carta posterior, de Huánuco, 12 de marzo de 1903, ${ }^{11}$ Gutiérrez alerta justamente contra El Huallaga, que "será siempre un elemento contrario a nosotros" por pertenecer a los poderes gamonales de esa región. ${ }^{12}$ Por otra parte, el subprefecto reclama amistosamente a Cáceres porque no le ha respondido una sola de sus cartas, a pesar que le ha escrito varias veces, dice. Luego prosigue sobre asuntos más serios, e informa que está organizando —al lado de Robles - las juntas distritales, cuyas actas serán remitidas al Comité Central Directivo. Asimismo, se compromete a reunir un cuerpo de redactores para hacer propaganda, junto con el mencionado Robles.

Por medio de la carta enviada desde Huánuco el 26 de marzo de 1903, nos informamos que Cáceres le había escrito a Gutiérrez el 18 de dicho mes y que lo recomendó ante el gobernador del distrito del Valle, Enrique Carrillo, hecho que nuestro personaje agradece. Señala además que Robles ha ido a Ambo a organizar la junta distrital; luego, el propio Gutiérrez irá a Panao para organizar allí el partido, junto con el mencionado Robles.

Gutiérrez no dejó de pensar en la situación de los trabajadores, aun cuando su balance sobre ellos no fuera positivo. En efecto, en su carta enviada desde Huánuco el 23 de abril de 1903, escribió a Cáceres sobre la clase obrera y los artesanos: relajados, falta de esfuerzo; persiguen la vagancia, mientras que la agricultura en los fundos languidece por falta de organización:

La agricultura en los fundos de montańa languidecía por falta de brazos; digo mal por falta de organización. Ideé y formulé un proyecto de enganche de operarios, una vez aplicado el cual, cada hacendado de montaña tendrá el número de peones que necesite y producirá en coca y otros artículos el cuádruple de lo hoy que produce, incrementándose al mismo tiempo, las entradas municipales.

11 La carta de Huánuco, 28 de febrero de 1903, es breve y específica: le informa de la separación de la gendarmería de un señor Jesús Cabello.

12 En su carta anterior (Huánuco, 19 de febrero de 1903), Gutiérrez prevenía que "los Durand y algunos como Pinzas" subvencionan con S/. 150 el periódico El Huallaga. 
Este proyecto ha sido de la aprobación unánime de los hacendados de montaña, lo he elevado a la prefectura y es probable que muy pronto principie a surtir sus efectos.

En Post Scriptum señala que quieren indisponerlo con el presidente, por lo que le ruega "se digne averiguar, desvirtuar lo que haya al respecto".

Por medio de la siguiente carta (Huánuco, 29 de abril de 1903) Gutiérrez continúa con el tema del P.S. de la misiva anterior. Alguien, según anota, quiere indisponerlo con el presidente Candamo. Está convencido de que se quiere dañar su "reputación militar". Le pide a Cáceres que sondee al presidente y que le haga saber lo injusto de esas acusaciones.

En la carta de Huánuco del 14 de mayo de 1903, Gutiérrez le comenta a Cáceres los conflictos políticos del lugar; habla de la influencia de Durand, del afán del prefecto de mantenerse en el poder en tiempos de elecciones. Y, como de costumbre, está preocupado por mejorar las condiciones de vida de los lugareños: planea la constitución de un camino en las montañas que se podría llevar a cabo con fondos particulares con el beneficio que se "acortará la distancia entre la montaña y la ciudad en ocho leguas". Asimismo, prepara "un reglamento de domésticas, pues el servicio aquí es calamidad".

La siguiente es la última carta que Gutiérrez envía desde Huánuco, está fechada el 21 de mayo de 1903, y en ella expresa sorpresa por su intempestivo cambio: "Muy en breve tendré el gusto de darle un abrazo de paso a mi nueva provincia y a la que he sido trasladado sin conocimiento de Ud. y en mérito de los trabajos de la causa que represento. Una vez en esa manifestaré a Ud. quien es el que ha tratado de desquiciarme". De igual manera, observa que han aparecido en los diarios El Tiempo y El Comercio "telegramas y correspondencias que el Sr. Prefecto...y lo más selecto de Huánuco han desmentido por medio de telegramas a S. E. y a los periódicos. Es una infamia y una indignación”. Y desde el plano político informa que el domingo 24 se presentarán los partidos Constitucional y Civil. Con esta comunicación, Gutiérrez culmina su conjunto de cartas enviadas como subprefecto de Huánuco, en adelante lo hará desde ese mismo cargo, pero esta vez desde Canta.

\section{La breve gestión como subprefecto de Canta}

Aquí se puede observar a un Teodomiro Gutiérrez dedicado de lleno a su gestión como autoridad, proponiendo obras, ideando el desarrollo de la región, buscando presupuesto para esas obras o convocando a la población para que, aunando esfuerzos y objetivos, puedan sacar adelante su localidad. Este es un Gutiérrez diferente al que estamos acostumbrados a ver, el enfrascado en luchas políticas, especialmente con los poderes locales que lo veían como a un enemigo peligroso para sus intereses. Lo malo fue que este momento duró muy poco, apenas dos meses.

En su primera carta desde Canta, el 29 de setiembre de 1903, Gutiérrez — luego de enviar saludos al general, a su esposa Antonia, a sus hijas Zoila y Hortencia y al esposo de esta, Carlos, lo que nos permite saber el nivel de confianza que se tenían-, le transmite su asombro ante la realidad que acaba de conocer:

¿Podría Ud. imaginarse nunca mi Gral. que Canta, provincia del departamento de Lima y a tan poca distancia de la capital de la República se encuentra en mayor atraso y abatimiento que muchas provincias del interior? Pues tal es Sr. el estado de esta infortunada provincia”. Ante dicha situación se propone hacer cambios: una carretera que una Canta con Chocas, "para lo cual he pedido al prefecto que exija a la Junta Departamental el envío de los cinco o seis mil soles que se han consignado en el presupuesto para refacción de caminos.

Además, piensa edificar una represa de las lagunas de Chupa-Cocha construyendo "un muro que cierre la quebrada, con piedra y champa [...] El muro tendrá cerca de 80 metros de largo por 6 de alto y $31 \frac{1}{2}$ de ancho con un chaflan exterior. Solo en la compuerta emplearé 5 barriles de cimiento romano, la que será de fierro y con tornillo para subir y bajar. Por todo se gastará al alrededor de s/. 300”. Con esta obra habrá agua y la agricultura se desarrollará, prevé.

En su siguiente carta (Canta, 12 de octubre de 1903), Gutiérrez le escribe a Carlos Porras - yerno de Cáceres-, y en ella le informa que sus enemigos - "un Rivero y un Vera Tudela" - quieren perjudicarlo, ante lo cual le pide que en el presupuesto de 1904 figure la represa que hemos visto mencionada en la carta anterior. Si ello no es posible, le informa 
que está determinado a construir el muro al estilo primitivo o incaico, contando con la contribución generosa de los vecinos de la zona.

La comunicación con Cáceres es continuada por Gutiérrez en la posterior misiva (Canta, 20 de octubre de 1903), y por ella sabemos que el general le había escrito con fecha 11 de octubre. Gutiérrez no oculta su satisfacción. Inmediatamente después, le comenta que ha ganado muchos amigos con base a las obras que ha proyectado realizar en la zona, y que son las mismas que expuso en la carta anteriormente reseñada, que implican agua y carretera. Al final de la primera página de esta carta, se encuentra una anotación a lápiz que muy probablemente sea del propio Cáceres. En breves líneas lo felicita con las siguientes palabras: "Me felicito que sus esfuerzos como autoridad serán debidamente apreciados en esa, y los buenos propósitos que tiene U. para llevar a cabo obras de utilidad pública y de verdadera importancia para esa localidad".

\section{Subprefecto de Chucuito y el gamonalismo en su estado puro}

Desde la fecha de la carta anterior (20 de octubre de 1903) no se conoce otra de Gutiérrez sino hasta el 7 de enero de 1904, cuando le escribe a Cáceres, pero esta vez desde la ciudad de Juli —en donde residía designado por el propio presidente Candamo para cumplir funciones de subprefecto de Chucuito-, y a la que llegó el 17 de diciembre, según le cuenta a Cáceres. Igualmente, le comenta que fue muy bien recibido por los pobladores a los que — vía los distritos- distribuyó su "manifiesto en español y aymara, y publicado por bando en decreto en ambos idiomas". ${ }^{13}$ Lo interesante es que estos documentos se los envió a Santiago Giraldo, ${ }^{14}$ director de El Indio,

13 El señor Adolfo Villanueva, escribe a Cáceres desde Juli, el 14 de enero de 1904, para manifestarle que: "La recepción del nuevo subprefecto señor Comandante Gutiérrez ha sido lo más complacida, toda la provincia se halla regocijada con tan digna y justa autoridad".

14 El abogado y periodista puneño Santiago Giraldo fue un gran defensor de los indios. Fue el primero, en el ańo 1901, en utilizar el término gamonal, lo hizo en el Memorial escrito en defensa de los reclamos que los propios indios puneños le habían hecho conocer al presidente Candamo. Ante ello, el jefe de Estado pidió un informe a Alejandro Maguiña, luego del cual decidió nombrar a Gutiérrez subprefecto de Chucuito. Luis Gallegos A., Un héroe del pueblo. El caballero del Altiplano, Rumi Maqui, Centro de Estudios y Reflexión para que los publique en su revista ("periódico" dice Gutiérrez), lo que efectivamente hizo. En un breve resumen, los textos señalan lo siguiente.

En el bando firmado por Gutiérrez (subprefecto) y Daniel A. Estrada Luna (secretario), Juli, 1 de enero de 1904, se plantea en sus considerandos: la necesidad de hacer cumplir la ley, que la raza indígena es explotada y que la esclavitud ya ha sido abolida en nuestro país; ante ello, se resuelve abolir los servicios forzosos y gentiles, el que los gobernadores nombren alfereces para las fiestas y el cobro por exención de este servicio, el reparto forzoso de dinero para lanas por atentar contra la libertad industrial y comercial, por ello, los indios reciben autorización "para entregar a la Sub-Prefectura las cantidades que hayan recibido por la fuerza". Por otra parte, no están obligados a realizar trabajos gratis, y deben exigir precios justos "por el combustible, ganado, víveres y demás que traigan a las poblaciones"; no deberán recibir presión para realizar sus matrimonios, pues estos deben ser resultados de su libre voluntad. Asimismo, los gobernadores impedirán que los curas cobren "debiendo sujetarse estos al arancel eclesiástico que debe fijarse en las puertas de las iglesias y en los lugares más visibles, tanto en español como en aymara para conocimiento de todos”, y prohibirán que los tenientes gobernadores realicen colectas en los caceríos de indígenas (Gutiérrez \& Estrada Luna, Bando de Teodomiro Gutiérrez, subprefecto de la Provincia de Chucuito, 1904, pág. 6).

En el otro documento, "Manifiesto del SubPrefecto de la Provincia de Chucuito a los pueblos de su mando", que fue publicado también en aymara, firmado por Teodomiro Gutiérrez, Juli, 25 de diciembre de 1903, es enfático en señalar -relevando que así lo quiere el propio presidente Manuel Candamoque los indios deben ser integrados plenamente a la

del Altiplano, Puno, 1973, págs. 3-4. El informe Maguińa completo fue presentado en la Memoria del Ministerio de Fomento ante el Congreso de 1902 y reimpreso luego en Santiago Giraldo, (editor), La raza indigena en los albores del siglo XX Imprenta de Víctor A. Torres, Lima, 1903. Giraldo no solo defendió los derechos de los indios sino también de los trabajadores en general, abogando por la jornada laboral de 8 horas, el derecho a la huelga, entre otras reivindicaciones. Consúltese Discursos del H. Diputado por Huancané Dr. D. Santiago Giraldo. Legislatura de 1900, Imprenta y Encuadernación Víctor A. Torres, Lima, 1900. Consúltese: Ximena Málaga Sabogal, "La educación racializada: políticas educativas para indígenas a inicios del siglo XX. El caso de Puno", Tesis para optar el grado de Magíster en Historia, Pontificia Universidad Católica del Perú, Lima, Setiembre, 2014 
República, anulando para ello todos los abusos que se cometen contra ellos (Gutiérrez, 1904, pág. 7).

En otras líneas de la misma carta aparece un dato más, y muy importante: que Gutiérrez fue designado para ese cargo gracias a la intervención de Cáceres: "Hago, pues, mi querido general todo lo posible por interpretar fielmente las miras del gobierno y por hacerme digno de la valiosísima recomendación que se dignó Ud. hacer a S.E. en mi favor". Como no podía faltar, está presente la evaluación política:

El ex subprefecto [Mariano V.] Cuentas es aquí un elemento funestísimo; ha sido, y quiere seguir siendo como Alcalde Municipal el principal exaccionador y enemigo de los indios con cuyas lágrimas ha amasado su fortuna. Seguramente tengo que adaptar alguna medida para tranquilidad de la provincia por que la indiada en masa odia á Cuentas y ha ofrecido entrar á esta ciudad para lincharlo si se encapricha en ser Alcalde. Imagínese Ud. Sr. el peligro que correría esta población con una irrupción de la indiada, peligro que he hecho conocer a la municipalidad, al Sr. Prefecto y á S.E. de lo que resulte será responsable la municipalidad únicamente.

Finalmente, la recomendación: "El que más apoya a Cuentas es su amigo el cura Manrique Fermín, sería bueno que le escribiera Ud.". ${ }^{15}$

El siguiente ańo —-1904 - sería especialmente intenso y mostraría en toda su plenitud el poder de los gamonales. En nueva carta (Juli, 28 de enero de 1904), Gutiérrez ofrece a Cáceres un rápido panorama de los conflictos que han suscitado sus proclamas con los poderes locales, especialmente con Cuentas y sus amigos: “...llegó Cuentas de Arequipa y viendo que se le había aguado la gran mina que

15 Precisamente el cura Manrique se dirigiría a Cáceres (Juli, 4 de febrero de 1904) para manifestarle la incomodidad que está causando Gutiérrez entre los poderes locales: "El nombramiento de subprefecto en la persona del Sr. Teodomiro Gutiérrez, fue celebrada por todos los constitucionales de la provincia, porque en el veíamos un factor más para el progreso del partido; yo como jefe de esta agrupación política de esta traté de rodearlo de los mejores amigos y cumpliendo con mi deber lo atendí debidamente en casa; diariamente lo aconsejaba a fin de que cambiara de rumbo en el sendero escabroso que, por instrucciones del Dr. Giraldo, había adoptado desde el principio, en favor de los indios, con notable prejuicio de los mistis, pero todo en vano pues día a día ha ido creciendo su terquedad, al extremo de haber causado, con sus bandos y proclamas puentes, la indignación general de todos los vecinos notables". Y agrega posteriormente: "El Sr. Gutiérrez es demasiado exagerado en sus determinaciones en favor de los indios...”. explotaba principió á celebrar reuniones y manifestar á sus compadres, parientes y amigos que felizmente son pocos que mis disposiciones eran una amenaza contra la propiedad, que debían protestar, quejarse al gobierno, armarse para imponerse por la fuerza y por ultimo pedir mi separación". A Cuentas - continúa Gutiérrez- no le conviene que los indios abran los ojos y ello lo hace peligroso. Un representante del civilismo, el señor Tovar, es su pariente y puede indisponerlo e incluso hacer llegar su mala información al propio Cáceres; de ser así Gutiérrez le pide a su mentor que lo regresen a Canta, donde la gente le ha demostrado cariño. El héroe de La Breña le responde con anotaciones a lápiz calmándole, diciéndole que el gobierno conoce la situación en Chucuito y que por eso lo ha designado a él, a Gutiérrez, como subprefecto, y que cumpla tranquilo con su deber sin tomar en cuenta los cargos que se formulen en contra de él.

Dentro de ese tenor, llegan al despacho de Cáceres comunicaciones apremiantes, angustiadas, incluso amenazantes de los gamonales de Chucuito para descalificar el accionar de Gutiérrez. Una de esas misivas es la firmada por Juan Octavio Caro (Puno, 4 de febrero de 1904), otro notable de la zona, advirtiéndole que "la indiada" está siendo sublevada por Gutiérrez:

...me permito dirigirle la presente, para manifestarle del modo más imparcial la incalificable conducta del Sub-Prefecto de la provincia de Chucuito donde resido, Dn. Teodomiro Gutiérrez, el cual ha obligado a todos los vecinos notables, en número de más de sesenta ha venir a buscar garantías a la capital del departamento, pues no solo nuestras vidas, sino también nuestras familias y propiedades se encuentran amenazadas por una eminente sublevación de la indiada a cuya cabeza se ha colocado el mencionado funcionario. ${ }^{16}$

Nuevamente, Gutiérrez (Juli, 3 de marzo de 1904) informa a Cáceres que sus enemigos están siendo derrotados, y que han aparecido artículos halagüeños sobre él en diferentes periódicos. Pero Cuentas, el que más explota a "la indiada", insiste con su amigo Andrés Aramburú para que publique en La Opinión

16 Las cartas que no son de Gutiérrez, sino de otros personajes de Chucuito que escriben a Cáceres especialmente para cuestionar al subprefecto, también se hallan en el Archivo Andrés A. Cáceres de la Biblioteca Nacional del Perú. 
Nacional artículos contra él: "Este Cuentas —escribe Gutiérrez- debería estar en la penitenciaría por sus crímenes y por cuanto ha hecho en esta". El tenor continúa en la siguiente carta (Juli, 31 de marzo de 1904), fustigando contra Cuentas — que "no es Dr. [...] es uno que apenas sabe chapurrear el castellano pero es maestro en el arte de explotar á los indios"-, quien "al ver mi inmensa popularidad con la indiada que me aclama, que me proclama su protector, que dice haber bajado yo del cielo para redimir su raza, creyó desde el primer momento, pero sin fundamento alguno, que iba a escudriñar sus picardías que iba a descubrir sus robos, que iba á hacerle toda clase de daños, por que un ladrón cree, mi Gral. que todos son de sus condición...”.

Luego, Gutiérrez realiza una acusación durísima contra el cura Manrique, "un hombre depravado, infame, inmoral y cuanto de malo puede tener un hombre. Este se ha hecho mi enemigo por que es compadre de Cuentas, después de haber sido su acérrimo enemigo por que Cuentas ha sido pierolista fanático y ahora se la da de cacerista o de civilista y no es ni lo uno ni lo otro". Igualmente, Caro, "un tinterillo de mala ley como todos los de sus especie, llevó su audacia hasta desacatarme e insultarme, pero hice caer sobre sus hombros todo el peso de mi autoridad, lo prendí, lo remití a Puno y lo sometí a juicio militar”. Este es el juego de poder al que se enfrentó Gutiérrez. Los poderes locales, es decir, los gamonales, en contra de cualquier mejora en la vida de los indios a los que exaccionan todo el trabajo que pueden para su beneficio particular.

Finalmente, Gutiérrez celebra la llegada de José Cavero, fiscal de la Corte Suprema: "Su alta investidura su intachable honorabilidad, el prestigio de su nombre, todo ha de contribuir a que el éxito de su visita haga época en los anales de nuestra historia". Por algo, la publicación El Indio (Año I, núm. 2, Lima, 22 de marzo de 1904) estampa su foto en la primera página acompañada de un texto que destaca la importancia de la situación del poblador indígena, tanto en lo social, político y cultural, destacando "la actitud enérgica y templada del subprefecto de Chucuito", y poniendo en relieve la delegación encomendada a Cavero — personaje reputado de su tiempo-,${ }^{17} \mathrm{cual}$

17 José Cavero Ovalle (1850-1940), fue uno de los que acompañaron a Andrés A. Cáceres en la campaña de La Breña, incluso llegó a ser su secretario. En ese tiempo histórico conoció a Teodomiro Gutiérrez, es la de resolver el problema indígena. En la página 6 es transcrito el Decreto Supremo mediante el cual se designa el objetivo de su comisión:

Comisionado

Del Supremo Gobierno

Ministerio de Gobierno

Lima, $1^{\circ}$ de marzo de 1904

Señor doctor don José Salvador Cavero, Fiscal de

la Excelentísima Corte Suprema de Justicia.

Con fecha de ayer se ha expedido la suprema resolución que sigue:

Siendo indispensable y urgente conocer las verdaderas causas de los disturbios que a menudo se originan en algunos territorios poblados por indígenas, entre estos y los funcionarios y vecinos de pueblos, y habiéndose prestado a llenar ese encargo importante el señor Fiscal de la Excma. Corte Suprema de Justicia, doctor don José Salvador Cavero, que posee el idioma de los naturales de aquellos territorios;

Se dispone:

Comisionar al referido Fiscal Dr. Cavero para que, constituyéndose en los departamentos de Ancash, Junín y Puno, con el propósito relacionado, proce$\mathrm{da}$ en el sentido de las instrucciones verbales que recibirá del ministerio de gobierno y dé cuenta oportunamente en circunstanciado informe, del resultado de la comisión. Regístrese, comuníquese y publíquese, Rubrica de S.E.- Quintana.

Que me es satisfactorio trascribir a US. para su inteligencia y demás efectos; manifestándole que el gobierno descansa en que US. con sus relevantes aptitudes y la decidida voluntad que lo animó siempre para el servicio del país, dará cima, en las proporciones apetecidas, al importante encargo que se le hace.- a fin de que al informar US de su emisión, puedan los poderes del Estado adoptar las medidas que sean convenientes y oportunas, para poner término a la situación azarosa de las circunscripciones pobladas por indígenas.

Dios guarde a US.

Juan de D. Quintana

[Ministro de Gobierno y Policía]

Quintana, 1904, pág. 6)

Exactamente el día de remisión de la carta de Gutiérrez apenas reseñada, Cáceres recibe otra misiva de Octavio Caro (Juli, 3 de marzo de 1904) con

por ello se entiende las esperanzas de este en la intervención de Cavero en los conflictos sociales entre los indios y los gamonales de Chucuito. 
el mismo tenor de queja y hasta de cierta amenaza: “...me permito distraer su atención para ponerle en conocimiento que este Gutiérrez me ha ultrajado de la manera más arbitraria y me ha abochornado como no lo he sido ni en el tiempo que tomado por los contrarios de la causa de Ud., fui conducido preso a Moquegua. Llegará pronto la circunstancia, si no se pone remedio, que todos los amigos de Ud. Sr. General en esta provincia, abandonen la causa, por los ultrajes e injurias que les infiere el mencionado subprefecto, lo peor es que asegura que Ud. lo apoya y lo sostiene". Luego, continúa: "No solamente yo, sino el Sr. Cura Manrique y el Sr. Don Francisco Espezúa que, en el puesto principal que desempeña, uno como párroco y el otro como alcalde provincial han sido estropeados injusta y descaradamente". Finalmente, invoca: "Confiados pues, mi General, en la rectitud de su criterio, le suplicamos que en servicio de la justicia y de la lealtad que le profesamos, se interese eficazmente para obtener la remoción de la autoridad mencionada". ${ }^{18}$

La presión contra Cáceres es sumamente fuerte. Incluso, la esposa de Octavio Caro, Dolores Caro, en carta remitida desde Juli, el 24 de marzo de 1904, le escribe a Cáceres para sumarse a las quejas y denuncias contra Gutiérrez:

...este Sr. [Gutiérrez] desde que llegó por una aberración a hacerse cargo del puesto que ocupa, se ha rodeado de un circulo de individuos criminales, tales como don Gerardo Remigio Eduardo, cuyo nombre está considerado en la estadística criminal de la memoria administrativa representada por el ex Subprefecto de esta provincia, Sr. Mariano V. Cuentas, don Adolfo Villanueva, reo prófugo por homicidio, en la persona de un soldado chileno encargado de vigilar el orden, bajo las órdenes del Subdelegado, Sr. Miguel Luis Semir, en la Subdelegación de Tarata, perteneciente a Tacna cautiva; y otros individuos por el estilo, explotadores son los que tienen con sus rencillas, dividida la provincia, con su conducta retrograda, estos Sr.

18 De paso, Caro enfila contra Adolfo Villanueva, que anteriormente le había escrito al héroe: "Algunos desnaturalizados que han comprendido la utilidad que puede producirles la titulada defensa de los indios, se han propuesto atizar los odios y acrecentar la calumnia y dilatar nuestro descrédito. De esta especia es Adolfo Villanueva, individuo que tan solo por interés se ha titulado partidario nuestro y que se han atrevido a dirigirse a Ud. Sr. General, desprestigiándonos, sin recordar los feos antecedentes que lleva y el desprecio a que se ha hecho acreedor en esta ciudad, por su pésima conducta”.
General los enemigos de mi esposo y haciendo del Sr. Subprefecto su maniquí, han conseguido por medio de calumnias, que sea ultrajado, y cual reo criminal, lo han sacado de nuestro domicilio fracturando las cerraduras de las puertas lo ha puesto en el calabozo incomunicado, y en altas horas de la noche lo ha hecho conducir a la ciudad de Puno en una mula aparejada.

Este ambiente adverso permite entender que las líneas escritas por Gutiérrez trasunten cierta desesperación frente a los ataques de sus enemigos (que no son pocos ni débiles). Por esa razón, en nueva carta (Juli, 31 de marzo de 1904), le suplica a Cáceres que le asegure a Cavero "que soy verdadero y leal amigo de Ud. más bien dicho prevenirlo en mi favor...”. Dos semanas después (Puno, 15 de abril de 1904), Gutiérrez da cuenta de la enfermedad del presidente Candamo (quien moriría el 7 de mayo de 1904), y de su reemplazante, Serapio Calderón (miembro del civilismo y terrateniente del Cusco), quien sería Presidente del Perú en el año 1904.

Retratando la vida política de Puno, Gutiérrez nuevamente alude al trío Cuentas-Tovar y el cura Manrique (compadre de ellos dos, además de constitucionalista como Gutiérrez, pero que lo enfrenta directamente), agregando al prefecto de Puno, el seńor Salazar: "Con un prefecto como este no se puede servir y estoy expuesto a perder mi reputación y mi prestigio adquiridos ya”. Por ello, le ruega a Cáceres que trate de cambiarlo a Ayacucho, Cerro de Pasco o Cajamarca. Gutiérrez considera que lo odian porque ha hecho cumplir sus bandos al pie de la letra enfrentando todo tipo de abusos contra los indios: “...mi Gral. los memoriales de los indios son pálidos ante la realidad de lo que aquí pasa". En la siguiente carta (Puno, 26 de abril de 1904), Gutiérrez le confiesa a Cáceres que la influencia de Tovar lo deja maniatado para cumplir sus proyectos.

En carta de Juli, del 4 de mayo de 1904, Gutiérrez incorpora un nuevo elemento en el panorama político de la zona, el hermano de Cuentas:

...gobernador de Ilave apoyado en la protección que le dispensa el Prefecto tuvo la audacia de recorrer las calles de Ilave durante mi visita a este pueblo, dando mueras á mí y haciendo tiros, acompańado de cuatro o cinco mas. Cuando salí a prenderlo huyo pero lo he suspendido de su 
empleo y lo he sometido a juicio militar, pero el Prefecto se hace el sordo y estoy seguro que dejará impune este grave atentado, este delito de rebelión contra mi autoridad como ha dejado impunes muchos otros dando alas á mis contrarios que felizmente han comparecido que no les tengo miedo á pesar de la reducida guarnición que me ha dado el Prefecto.

Agrega que es un honor "civilizar á toda una población de 40000 indígenas y hacerlos útiles á la sociedad, á la familia y á la patria”.

Opuesta es la visión de otro representante de los poderes locales de Puno, cual es Romero V. Benavides. En su carta desde Puno, el 10 de mayo de 1904 , en vísperas de la campaña electoral, le manifiesta a Cáceres:

En las actuales circunstancias en la que me parece legal y correcto que [...] los del partido nos pongamos en pie para trabajar por el candidato que U. nos designe, no puedo menos que manifestarle que por correo de antenoche he recibido carta de los amigos de la provincia de Chucuito, como un Espezúa, Franco y otros en que se insinúan que le dirija la presente manifestándole que una vez que llega [sic] el momento supremo de las elecciones, conviene el cambio del Subprefecto Gutiérrez quien un tanto [sic] se ha hecho imposible por estar en su contra la mayoría de los pueblos.

En su carta desde Juli, el 19 de mayo de 1904, Gutiérrez da cuenta del desenlace previsto en su carta anterior: "...el Prefecto repuso al gobernador, le mandó gendarmes y ha hecho caso omiso de mi petición, dejando atónito y escandalizado al pueblo de Ilave que ha presenciado y es testigo del atentado cometido por el Gobernador, quien hace alarde de la protección del Prefecto diciendo que este tienen motivos, poderosos para sostenerlo". El prefecto, Salazar, "no es sino un farsante". Finalmente, en el PS pregunta por la actualidad política y partidaria: "¿Quiénes son nuestros candidatos a la Presidencia y Vicepresidencia?”.

En nueva comunicación (Juli, 25 de mayo de 1904), el subprefecto se refiere al cura Manrique como un enemigo, a pesar de ser cacerista. Igualmente ocurre con el señor Caro, un tinterillo que dice ser constitucional pero que solo es un explotador de indios. Finalmente, Cuentas, "apoyado por el Prefecto me está también fastidiando, pero no espero sino la llegada del delegado Dr. Cavero para desenmascararlo y presentarlo ante este distinguido magistrado en toda su repugnante desnudez". Cambiando de tema, pero volviendo al asunto electoral del PS de la carta anterior, Gutiérrez inquiere sobre si su partido lanzará candidato o si apoyará al del civilismo, "pues, según cablegramas publicados en los periódicos de Puno, Ud. ha ofrecido al Dr. Pardo su eficaz y poderosa colaboración".

Los enemigos de Gutiérrez no le dan tregua, y apuntan a hacerle perder credibilidad ante el propio Cáceres. Nuevamente, Simón Gonzales (Puno, 7 de junio de 1904) le escribe en medio del ambiente electoral y de la decisión del constitucionalismo de ir en alianza con el civilismo (como en el año 1903) bajo la fórmula José Pardo-José Cavero (que finalmente ganaría los comicios), lo que le sirve de pretexto para enfilar contra el Subprefecto:

De la provincia de Chucuito, me escriben en tono de desesperación, rogando que se cambie al Subprefecto actual quien parece que se ha puesto en completa interdicción con los vecinos, es por esto que ayer me permití dirigirle un telegrama para que apoye ese cambio, que es de unidad actual para aprovechar los elementos de esa provincia que actualmente se resisten a tomar parte en la política, excusándose con los desaires que reciben del señor Gutiérrez, Creo que si continua esté señor en esa provincia, esta se perderá para la alianza y mucho me temo que se conviertan en propagandistas de la oposición y que avancen fuera del terreno legal.

Una semana después (Juli, 15 de junio de 1904) alguien escribe a Gonzales (la carta está incompleta, y no aparece firma) señalando que tiene resentimiento contra Cáceres "a causa de sus cartas casi hirientes a nuestra dignidad, en las solicitudes que hemos hecho para el retiro de esta provincia del actual subprefecto D. Teodomiro Gutiérrez". En verdad, casi toda la carta (o lo que conocemos de ella) se refiere a Gutiérrez:

Yo he dicho al general más de una vez y tuve la hidalguía de decirle también al finado Presidente Sr. Candamo (por lo que no me quería mucho) que ésta provincia era esencialmente constitucional; esto nadie ha podido negarlo, como U. lo sabe; por consiguiente: siendo los vecinos de esta pro- 
vincia, estafadores, de los indios, abusivos, gamonales [...]. Tiene que decirse necesariamente, que son los constitucionales los que tal hacen. Dice también el general que el Sr. Gutiérrez ha venido enviado a esta provincia, justamente como persona a propósito para devolver a los infelices indios las garantías que habían perdido y desterrar los abusos y atropellos de que venían siendo víctimas, y termina diciendo que nuestras quejas, es decir de los constitucionales que escribimos al jefe del partido, son la consecuencia de las instrucciones traídas por Gutiérrez y las medidas que habrá tomado para detener vicios arraigados y en persiste en decir que Gutiérrez por sus buenas cualidades circunspección e inteligencia, es incapaz de cometer abusos. Así pues, que no es cierto cuanto le han dicho los constitucionales por cartas al general, del mal procedimiento de Gutiérrez; somos unos farsantes mentirosos y Gutiérrez es el único hombre perfecto.

Como el partido constitucional está compuesto de cuanto digno tiene el país, no merecen el nombre de tales constitucionales los vecinos de la provincia de Chucuito.

Cuando Gutiérrez principio sus estorciones y ya se dejaba sentir el desquiciamiento entre vecinos e indios, le hice notar lo mal que hacia, y en razón de ser mi amigo y estar alojado en mi casa, le supliqué, a nombre del partido constitucional, que fuese más pru[dente]... ${ }^{19}$

El tenor de la carta desde Juli, 22 de junio de 1904, es el mismo que el que vimos en la anterior comunicación: "No puede Ud. imaginarse la guerra cruda que me han hecho y siguen haciéndome estos individuos, tan solo por que no me he prestado a ser su maniquí y por que he hecho prácticas las disposiciones del Supremo Gobierno, entre ellos la abolición de los servicios gratuitos y forzosos y la del reparto forzoso para lanas". Como sus enemigos vieron que sus amenazas e infundios no tenían efectos positivos para ellos, decidieron llevar las cosas a la práctica: volaron con dinamita la ventana del dormitorio del subprefecto, pero al ver que este no se amedrentaba, le enviaron a Gutiérrez cartas anónimas amenazándolo con quemar su casa. Tampoco les hizo caso. Incluso, lo quisieron incriminar con documentos en los que habían falsificado su letra, pero después de muchos inconvenientes, Gutiérrez pudo salir airo-

19 Aquí se interrumpe la carta. so. Luego, enviaron un telegrama como si el propio Gutiérrez renunciara a su cargo. Resultados infructuosos, igualmente.

En medio de todo este enfrentamiento contra Gutiérrez, llega a Cáceres una carta de apoyo al trabajo del subprefecto. En efecto, Luis Romero (Juli, 25 de mayo de 1904) elogia el comportamiento de aquel: "Tenemos de Subprefecto al Sr. Clodomiro [sic] A. Gutiérrez, quien sin lisonja ninguna está portándose con la integridad que le es característica a un caballero, y aun cuando un Mariano Cuentas se ha presentado como gratuito enemigo de él, por no haber concedido a las exigencias contrarias a la ley y porque es decidido protector de la raza indígena, el Sr. Gutiérrez hace caso omiso de tales pretensiones, porque en su mismo pueblo, es decir, a Cuentas que es Ilave, unánimes se han levantado al sostenimiento de la autoridad justiciera de dicho Sr. Gutiérrez".

En líneas escritas a lápiz, Cáceres expresa su contento: "Celebro mucho que el Sr. Gutiérrez Subprefecto de esa, le merezca tan buena opinión y que los aborígenes estén convencidos de las buenas intenciones de este funcionario. Espero que como en el pasada elección contribuya con su prestigio y relaciones hasta conseguir el éxito". Se observa que el héroe continúa apoyando a Gutiérrez aun en un clima tan altamente hostil contra este, aunque ello suponga contravenir los deseos de los gamonales de esa zona.

Francisco Espezúa, uno de los sindicados por Gutiérrez como su enemigo, remite una carta a Cáceres (Juli, 22 de junio de 1904) manifestando su resentimiento para con el héroe. Por ello es probable que quien escribiera la carta incompleta anterior sea el mismo Espezúa. Le transmite lo que se rumorea, que el propio general sostiene "al tirano Gutiérrez", autócrata, que persigue a los ciudadanos (es decir, a los notables), y que de continuar esa situación "se abstendrán de las elecciones”. El remitente continúa con su acusación y emite una sentencia: "El Sr. Gutiérrez a pesar de ser del partido, ha sido su peor enemigo y a él se le deberá que quizá desaparezca el partido en esta provincia”. Dos días después (Puno, 24 de junio de 1904), Simón Gonzales vuelve a escribir con su ya evidente tono amargo, para decirle a Cáceres que los vecinos de Pomata "se quejan de U. por el apoyo que dicen presta al Subprefecto Gutiérrez", y que ese 
ejemplo puede cundir. ${ }^{20}$ Le reitera su pedido de que Gutiérrez sea cambiado de provincia "en nombre de los intereses del partido, y en el de la tranquilidad de la Chucuito". Y finaliza remarcando lo que ya le habían comunicado antes a Cáceres: que el subprefecto tiene un círculo de compañía reprobable.

Es evidente la estrategia de los gamonales de Chucuito: presionar a Cáceres para que le quite su apoyo a Gutiérrez apelando a sus lealtades partidaristas. El general se ve forzado a remitir algunas líneas como respuesta. En ellas dice - bajo su modalidad de hacer anotaciones a lápiz en la misma misiva, pero lamentablemente incompletas - "que con la oposición que ellos hacen a Gutiérrez, se declaran como los verdaderos autores y causantes de la dolorosa condición en que ha estado en esa la clase indígena, víctimas de mil exacciones y abusos, no de otro modo puede explicarse nadie que personas que por su carácter sacerdotales como por la posición que ocupan que debían ser los primeros en prestar su apoyo y su [...] a una autoridad cuyo [...]". Las líneas no están completas pero se entiende el sentido: Cáceres critica a los poderes de la zona, y de paso apoya a Gutiérrez, con lo cual los deja completamente descolocados.

No olvidemos que Cáceres combatió al ejército chileno con el fundamental apoyo indígena, pero también recordemos que poco antes había sido Prefecto del Cusco — desde el 21 de noviembre de 1877 hasta abril de 1878 - Su gestión estuvo marcada por distintos temas, especialmente, el combate al abuso en contra de los indios. En diferentes comunicaciones se descubre a un Cáceres atento a los vejámenes a los que eran sometidos los campesinos indígenas, a quienes consideraba parte integrante de la nacionalidad, en posición opuesta a la de los gamonales, que los trataban con impiedad. Como le escribe al Subprefecto de Quispicanchis: "Los indígenas no forman una fracción distinta de la familia peruana: raza que por lo mismo de encontrarse en el estado de abyección a que inhumanamente se le sujeta, reclama una preferente protección de parte de esas autoridades que ha recibido la misión de prestar-

20 Según le informa Alejandro Bustamante (Puno, 5 de julio de 1904) a Cáceres, efectivamente, en el periódico La Luz los vecinos de Pomata comunican su separación del Partido Constitucional y que se sumarán a otro partido. le todo el auxilio, para que salga del estado de ignorancia y miseria a que se halla reducida".

Cáceres combatió el servicio personal, las flagelaciones, los encarcelamientos y maltratos, el robo de los ganados de los campesinos y otros abusos, todo lo cual calificaba de "detestable conducta abusiva". Y así como denunciaba a los hacendados, igual lo hacía con las autoridades políticas y eclesiásticas que aprovechaban de su poder para someter al indio. Se trata de una descripción descarnada de la situación del habitante andino que, en las décadas posteriores, daría paso al movimiento pro-indígena que coparía las discusiones sobre la nacionalidad (Castro Lizarbe, 2014). Es fácil explicarnos las razones de su apoyo a Gutiérrez quien como subprefecto emuló la conducta de su mentor. Pero el tiempo previo a la Guerra con Chile es distinto al de los inicios del siglo XX, como veremos después.

El 5 de julio de 1904, Ismael, Obispo de Puno, se dirige a Cáceres desde esa ciudad para sumarse al cargamontón gamonal contra Gutiérrez: "Ahora que he estado en la provincia de Chucuito, me he impuesto que los vecinos de ella creen que $U$. sostiene al Subprefecto Gutiérrez, que está mal con muchos de ellos, y esto es un argumento para hacerse anticaceristas". Qué cierto aquello de la alianza de las élites eclesiásticas con los poderes locales. ${ }^{21}$

Mientras tanto, Gutiérrez continúa con su intensa comunicación con Cáceres. En su carta de Juli, 7 de julio de 1904, agrega un giro más en la persecución contra el subprefecto. Este informa a Cáceres que sus enemigos ensayaron un último recurso: culpar al propio Cáceres:

...de que se le llame gamonales y de que se les diga ladrones. El cura Aragón tránsfuga del partido Constitucional desde el año 94 en que se hizo pierolista, ha influido en algunos para formular el acta más estúpida y que los presentará ante la

21 Romeo V. Benavides (Puno, 20 de julio de 1904) con otra información tiene un análisis diferente sobre el tema, cuando expresa: "En la provincia de Chucuito, pretendiendo hacer un dańo al Subprefecto Gutiérrez, el señor Aragón cura de Pomata, ha hecho firmar inconscientemente a alguno de nuestros amigos una acta tratando de querer tratar a U. como su amigo, creyendo que U. apoyaba a Gutiérrez, pero más con la carta tan terminante que ha escrito $\mathrm{U}$. al amigo González, he hecho que todos los amigos de la provincia protesten contra aquella acta, y que declaren terminantemente que ellos son constitucionales Caceristas, como vera U. en el periódico 'El Inca' que le remito". 
República entera como á enemigos acérrimos de los indios y de todos lo que quieran trabajar en su favor, sin más propósito que impedir la ilustración y civilización de los indios para que, ignorantes como siempre, se dejen explotar inconsideradamente con crueldad é inhumanidad.

Gutiérrez lamenta que Cavero no hubiera podido visitarlos como prometió, pero la sola noticia de su viaje atemorizó a los poderes locales de Chucuito, más ahora que es el candidato a la primera vice presidencia de la República, apoyando la candidatura de José Pardo, en la alianza civil-constitucionalismo. Ya se nota a un Gutiérrez cansado de tanta oposición: "Estoy ansioso de salir de aquí no por cobardía por que no puedo acusarme de ese pecado, pues al respecto les he dado á éstos pruebas palmarias, pero quisiera salir por que este es un infierno, un país de ladrones y semisalvajes como podrá decírselo a Ud. el Corl. Pizarro y el Dr. Benjamín B. Saez que han sido subprefectos de esta provincia”.

En la única carta enviada desde Ilave, 21 de julio de 1904, Gutiérrez da cuenta de un enemigo que antes había sido constitucionalista pero que luego pasaría al pierolismo en 1894, el cura Francisco E. Aragón. Por su parte, Gutiérrez apunta que Cuentas y sus secuaces no representan un peligro para las futuras elecciones. Pasando a otro tema, le pregunta a Cáceres si el coronel Acevedo podrá considerarlo para que recupere su "clase de mayor".

Para entonces, como señala Antonio Rengifo, la suerte estaba echada para Gutiérrez. La muerte de Candamo y la asunción de Calderón (terrateniente cusqueño) como Presidente del Perú atentó contra su mantenimiento en Chucuito, le despojó del apoyo político necesario al subprefecto. No tenemos total claridad si fue decisión del propio presidente exclusivamente o si fue Cáceres mismo el que le quitó la confianza a quien había sido su secretario (Rengifo, 1977). ${ }^{22}$ El resultado es el que sabemos: Gutiérrez fue despojado de su cargo de subprefecto.

22 Nelson Manrique en su texto Las guerrillas indigenas en la Guerra con Chile, ha señalado que hay que diferenciar al Cáceres militar que defendió el territorio peruano ante el ejército chileno, del Cáceres político, que rompió sus alianzas con los indios para ser aliado de los hacendados. Gutiérrez aprendió a valorar a los indios durante la campaña de La Breña y mantuvo dicha admiración mientras Cáceres no solo reviraba de sus posiciones indigenistas sino que incluso llegó a organizar una represión anticampesina.
Simón Gonzales vuelve a escribir (Puno, 26 de julio de 1904) pero con un tono de alivio, pues agradece a Cáceres que haya pedido ante el presidente Serapio Calderón la separación del subprefecto Gutiérrez de la provincia de Chucuito. Afirma que Cuentas es el autor de la situación y del malentendido haciendo correr la idea de que Cáceres apoyaba a Gutiérrez. Luego pasa a relatar su versión de la historia:

D. José Zapata vecino notable de Pomata [...] de acuerdo con Cuentas y con el cura Aragón, persuadieron con el engaño, a los constitucionales, hasta conseguir que firmasen una acta que fue redactada por Aragón y es la que se ha publicado, con la circunstancia notable, de que Aragón les ofreció firmar ese documento, lo que no hizo, según aparece de la publicación”. Finalmente, da a conocer la composición de la junta provincial del partido Constitucional: "Presidente Francisco Espezúa - Vicepresidente Fermín Manrique - Vocales Manuel Ezequiel Adrián, Casto Jiménez, Cleto [...] Cotacora y Víctor R. Gamarra - secretario Vidal Manrique.

Los enemigos de Gutiérrez ya pueden respirar tranquilos.

Pero Gutiérrez sigue entusiasmado y le asegura a Cáceres que el éxito electoral está asegurado, gracias a "una elección canónica" (Juli, 16 de agosto de 1904). Por ello, sus enemigos se presentan como leales de sus candidatos con la esperanza de que Cuentas sea nombrado Prefecto, lo que equivaldría, dice, a echar fuego a una situación ya explosiva. Asimismo, espera la visita, ahora sí, de Cavero, para que vea directamente la realidad de la zona, y solo le ruega a Cáceres que no lo cambie hasta que dicha visita tenga lugar.

La campaña contra Gutiérrez es intensa por parte de los gamonales de Chucuito. Quieren, a toda costa, que lo destituyan, y para ello urden complots. Gutiérrez, apoyado por dirigentes indígenas de Puno, se debe defender para contrarrestar la avanzada gamonal. Ese es el sentido de la siguiente comunicación al diario El Comercio de Lima, que reproduzco tal cual, con sus errores de redacción y de ortografía. 


\section{MEMORIALES}

El subprefecto de Chucuito

Lima, Agosto 19 de 1904.

Señores cronistas de "El Comercio"

Respetados señores:

El suelto que publican ustedes en la edición de la mañana de hoy de su acreditado diario titulado: "El Subprefecto de Chucuito", se funda en un telegrama anónimo que está desautorizado no sóle por por el otro telegrama inserto a renglón seguido del anterior en la misma edición de "El Comercio», si no también por el siguiente auténtico que acaba de recibir nuestro abogado.

\section{TELEGRAMA}

"Julio, agosto 18 de 1904

“á $7 \mathrm{~h}$. $45 \mathrm{~m}$. de la n.

"Doctor Giraldo

Lima

"Caro dice haberse dirigido telegrama doctor Pardo diciéndole que obstruyo actos electorales. Desmienta diciéndole que pido minintro enjuiciamiento calumniantes. Acúseme recibo.

"Gutiérrez"

Además se refiere usted a que los representantes por Puno solicitaron hace dos días del ministro de gobierno la destitución del subprefecto de Chucuito señor Teodomiro A. Gutiérres; pero desgraciadamente no se sabe hasta ahora quienes son esos seńores representantes ni cuales los motivos que les han obligado a asumir una actitud tan seria e inusitada; por lo que suplicaríamos a dichos senores representantes se dignaran hacer publica su acusación, a fin de cumplir por nuestra parte el encargo que tenemos de desvanecer los datos falsos que sin duda, para sorprender a los señores representantes, han suministrado algunos interesados en la destitución de dicho funcionario, nombrado con notorio acierto por nuestro nunca bien llorado protector, malogrado Excmo. señor Candamo.

Perdonen UU. señores cronistas que nos apresuremos a hacer esta rectificación, antes aún de haber anunciado a UU., como pensábamos nuestro arribo a esta capital, y las causas que nos vuelven a traer a las puertas del Palacio de Gobierno, en calidad de mensajeros de las comunidades indígenas; pues esperábamos para ello el resultado de las audiencias del Delegado doctor Cavero y del Excmo. señor Vicepresidente de la República que tenemos solicitadas.
No dudamos, seńores cronistas de la filantropía con que "El Comercio siempre ha defendido nuestros derechos, que nos abandonará en esta nueva etapa de triste y lacrimosa vía-crucis de la raza indígena.

Aprovechamos de esta oportunidad, señores cronistas, para repetirnos de UU. como siempre humildes servidores.

Mariano Charaja.

Mariano Huanca.

(Mensajeros de comunidades indígenas de Puno). (Charaja \& Huanca, 1904) $^{23}$

Todo lo descrito por Gutiérrez ya era conocido en diferentes partes del país. Una muestra es la primera página del número 3 de la ya mencionada revista $E l$ Indio. Ahí podemos leer a toda página, con foto central de nuestro personaje, lo siguiente:

"El indio"

La cuestión indígena del Perú presenta en estos momentos su punto culminante en la Provincia de Chucuito, donde se está librando una recia batalla moral entre los derechos del indio oprimido y los intereses del gamonal opresor.

¿Quién encarna la causa de humanidad y de ley en esa terrible lucha? -el subprefecto de la Provincia de Chucuito Comandante Dn. Teodomiro A. Gutiérrez.

Ocho meses ha que el Excmo. Sr. Candamo con esa penetración peculiar al ojo del estadista, señaló a Gutiérrez como al hombre capaz de realizar la obra que entonces se creía imposible, la garantía efectiva de los derechos del indio contra un secular sistema de ignominiosa opresión.

Pues bien, el Subprefecto Gutiérrez ha realizado ese imposible con sola su actitud enérgica y templada para hacer cumplir estrictamente la ley.

Y si se tiene en cuenta que para cumplir tan difícil misión con su inquebrantable voluntad una oposición formidable sistemáticamente organizada, oposición, que no ha economizado la falsedad ni la dinamita, hay que concluir que ese hombre es ante todo un carácter.

Bien podríamos insertar aquí los antecedentes del pundonoroso militar; pero el tiempo ni la índole de nuestra publicación nos lo permiten; y si por

23 La primera entrega de la revista El Indio (Lima, 18 de diciembre de 1903), está dedicado exclusivamente a las demandas de los mensajeros de Chucuito. En las líneas finales de su "Prospecto" se explicita su misión: "Por lo demás es preciso conste que El Indio no entra á la arena de la prensa en son de combate: nó: su misión es simplemente de persuasión y propaganda” (pág. 3). 
fin nos resolvemos a levantar la voz en defensa de ese funcionario, es porque a ello nos obliga la actitud que últimamente ha asumido un grupo de representantes del Departamento de Puno para imponer al gobierno la destitución incondicional del Subprefecto de Chucuito.

Nos permitimos pues llamar seriamente la atención del Supremo Gobierno hacia la calidad del hombre que hoy es importantísimo factor del problema nacional indígena y del que los intereses personalistas quieren probar a la desventurada raza.

Por lo demás, no podemos menos que dejar grabado en la primera página del tercer número de $\mathrm{El}$ Indio el retrato del digno Subprefecto. (El Indio, 1904, pág. 1)

En ese mismo número, Manuel González Prada publica un artículo de decidido apoyo a Gutiérrez.

"Autoridad humana"

La Provincia de Chucuito nos presenta un fenómeno muy raro en nuestra vida pública: algunos millares de indios clamando porque no se remueva de sus funciones a un subprefecto.

Vivimos acostumbrados a que los pueblos se duelan de sus malas autoridades y eleven inútiles reclamaciones al Gobierno; estamos cansados de leer actas populares, fraguadas por los procónsules, sus amigos o sus cómplices; mas, volvemos a decirlo, nos parece cosa muy rara el clamor sincero y espontáneo de treinta o cuarenta mil indígenas.

Para merecer el amor de sus subordinados ¿qué hace el subprefecto Gutiérrez? Cumplir algunas de las leyes distadas en favor de los indios. Llevando a la práctica lo que para muchas autoridades no pasó de letra muerta, ha conseguido abolir en su Provincia las mandas forzosas, los servicios gratuitos y las demás iniquidades sancionadas por la tradición. Con leyes humanas desarraigada costumbres feudales.

Se comprende que semejante variación en la manera de tratar a los indios suscite odios y resistencias. $\mathrm{Al}$ ver que los amigos de Gutiérrez son los pobres y los desheredados, ya se vislumbra quienes pueden ser sus enemigos. Estos le han declarado guerra sin cuartel: le denigran le calumnian, le chismean, le provocan riñas, le falsifican los documentos oficiales y hasta le arrojan bombas de dinamita a su domicilio (prueba que el uso de explosivos no pertenece exclusivamente a los anarquistas.)

Deponerle se ha convertido en cuestión parlamentaria. No hace muchos días que un grupo de Senadores y Diputados del Departamento de Puno solicitó la inmediata deposición de Gutiérrez. Los solicitantes no alegaron causa legal ni motivo serio; parece que alguien adujo como razón inamovible que no destituir al Subprefecto de Chucuito, después de haberlo solicitado una fracción del Congreso implicaba inferir un desaire a los Representantes. Lo de siempre: el gamonal que en las provincias fragua las elecciones tiene por defensor en Lima al elegido del fraude: simple cambio de servicios entre buenos compadres.

¿Cederá el Gobierno? ¿Veremos por centésima vez el triunfo de la iniquidad? Destituyendo a una hombre como el Subprefecto de Chucuito se revelaría que se antepone los intereses de un grupo a los grandes intereses de una colectividad, y que las buenas leyes se promulgan por mera fórmula no con el propósito de verlas cumplidas.

Los hombres públicos deben recordar que toda la vida de las naciones no se condensa en las luchas para elegir diputados, senadores y presidentes: no todos poseen derechos de votar; pero ninguno carece de vientre para comer. Hay una gran masa que no disfruta de leyes ni garantías, aunque paga contribuciones y presta servicio militar; da mucho, $y$ recibe nada o muy poco. Constituirse en el defensor y acaso en el padre de esta gran masa indefensa y explotada, hé aquí la aspiración más noble de un mandatario. Más que levarse como jefe de ricos y opresores vale gobernar para los desheredados y oprimidos.

En fin, lo que no pasa hoy de una queda sumisa o lamento humilde, puede convertirse mañana en un grito de rebelión, no para solo cambiar de autoridades secundarias, sino para conseguir una reivindicación social. Existe muchísima diferencia entre el motín de una soldadesca y el levantamiento de una raza para sacudir el yugo y vengar las iniquidades de tres a cuatro siglos.

Manuel G. Prada (González Prada, 1904, pág. 2)

En el mismo número de El Indio, pero en su página 3, se menciona la situación en Chucuito, señalando: "La condición legal de las comunidades indígenas de esta Provincia ha continuado mejorando, merced a la resistencia que el subprefecto Gutiérrez opone a los esfuerzos de la reacción gamonal". Continúa un poco después diciendo:

Fracasada la misión Cuentas, los gamonales se cobijaron bajo las alas protectoras del Prefecto del Departamento, quien llevó su parcialidad al extremo de violar la Constitución del Estado y las 
circulares del gobierno, nombrado por sí y ante sí Gobernadores tan hostiles al subprefecto que uno de ellos es de Ilave Juan Cuentas encabezó una sublevación armada que no mereció del Prefecto ni siquiera un simple decreto de enjuiciamiento, lo que obligó al subprefecto a denunciar el hecho ante el Consejo Supremo de Guerra y Marina, el que pidió informe al Prefecto que hasta ahora no sabemos si lo ha absuelto. (1904, pág. 3)

Como se puede observar, Gutiérrez permitió visibilizar la situación del indio en Puno, el poder nefasto de los gamonales — agentes abusivos e indolentes-, y su propia gestión a favor de la población indígena.

Obviamente, los enemigos de Gutiérrez se hicieron más enemigos de él. Juan Octavio Caro (Juli, 18 de agosto de 1904), luego de informar a Cáceres los resultados electorales (a favor de la alianza civilconstitucional) sostiene: "Habiendo sido nombrado Presidente de la Junta Escrutadora de sufragio de toda la provincia, he hecho cuanto he podido por nuestra causa, a pesar de las amenazas y abusos continuos del farsante de Gutiérrez...”. Para luego continuar con especial deleite: "Espero Sr. General que si las leyes son respetadas en el Perú, muy pronto al Subprefecto se le aplicará el rigor de ellas, y entonces tendremos el gusto de verlo prófugo, o en el cárcel, porque estos días saldrá auto de prisión en contra de él, por varios juicios que le sigo, lo que no dejaré de la mano, ya que no ha querido salir con honra". Mientras tanto, en el panorama político, la alianza civil-constitucional gana las elecciones generales y José Pardo y Barreda es elegido Presidente del Perú, el primer vice-presidente sería José Cavero, un acuerdo modernizante que, sin embargo, no pudo contrarrestar el poder gamonal puneño.

Los indios no quedaron conformes con la separación de Gutiérrez. El 4 de octubre toman Pomata en la antevíspera de la fiesta de la Virgen del Rosario. Los notables huyen aterrados, pero son apoyados por las autoridades de Puno, que envían un batallón del ejército en el vapor "Yapurá" además de gendarmes. Se inicia el fuego muriendo buen número de los indios rebeldes mientras lograban huir. Atrapan, enjuician y encarcelan a los cabecillas exagerando de paso los alcances del movimiento. Pero gracias a la labor de Dora Mayer y Santiago Giraldo, los encarcelados pudieron salir en libertad después de dos ańos (Rengifo, 1977, págs. 7-8). Gutiérrez se había ido, pero las razones del conflicto se mantenían intactas. Años después, Puno volvería a arder y Gutiérrez también volvería a estar ahí.

En este punto, se debe destacar la participación del abogado, pedagogo y periodista puneño Santiago Giraldo (1850-1929), diputado por Huancané entre los años 1896 y $1899,{ }^{24}$ además de ser uno de los que con mayor ardor defendieron a los indígenas contra los abusos de los gamonales. Las denuncias contra el gamonalismo y el apoyo a Gutiérrez aparecidas en $E l$ Indio, son producto de su personal preocupación por la situación del indígena, que conocía directamente. Desde sus diferentes facetas, Giraldo defendió la causa del indio abogando por su educación para incorporarlo plenamente a la nacionalidad. Debido a su rigor doctrinario, Giraldo sería uno de aquellos pensadores sociales fundamentales que reflexionó sobre el llamado "problema indígena", dejando una enseñanza trascendental a las nuevas generaciones, incluso las más ideológicas y políticas. En algún sentido se podría decir que Gutiérrez-Rumi Maqui representaba la aplicación práctica y militar de los postulados de Giraldo.

\section{Después de Chucuito}

Desde el Callao, 10 de noviembre de 1904, Gutiérrez envía una nota escueta a Cáceres para comunicarle que está enfermo de influenza y que por eso no puede visitarlo personalmente, pero aprovecha la oportunidad para dejar expreso su cariño y votos "para bien de la patria, de su digna familia y de sus amigos, muy particularmente de aquellos que en la Breña probaron a Ud. en cariño y adhesión de una manera irrefragable". Enseguida, la nueva carta es enviada desde Huánuco, 13 de diciembre de 1904, ciudad a la que

24 No he podido identificar a qué partido político perteneció Giraldo, pero es muy posible, que por sus posiciones críticas al sistema fuera socialista lo que de alguna manera lo colocaba cercano a la Unión Nacional y al anarquismo en general, representado por el pensador Manuel González Prada. En carta fechada en Barranco, 12 de enero de 1899, dirigida al director de Germinal, órgano de la Unión Nacional, le escribe pidiéndole poder colaborar en sus páginas: "La oportuna aparición del semanario independiente que U. dirige, y que, espero, ha de corresponder al programa de la 'Unión Nacional', me alienta á buscar un asilo en sus columnas, para ver si sería posible que mis ideas encontrasen acogida aquí...”. Santiago Giraldo, Legislación Militar. Crítica Parlamentaria por el H. Diputado..., Imprenta Portal de San Agustín No. 44, Lima, 1944, pág. 3. 
Gutiérrez volvió después de casi dos años. Esta vez desea que su mentor, el general Cáceres, lo ayude a ocupar el puesto de prefecto que dejará pronto el señor coronel González, de quien dice "se ha hecho antipático en esta ciudad y se encuentra completamente aislado".

Ya en Huánuco, Gutiérrez (Huánuco, 13 de diciembre de 1904) insiste en su pedido de reemplazar al prefecto, el Sr. González, con una promesa: "Como prefecto de este departamento estoy seguro hacer en pro de su adelanto y prosperidad lo que ningún otro prefecto porque tendré muchas facilidades y me creo un hombre y no especulador como muchos otros". La designación no se concretó y Gutiérrez ocuparía el puesto de subprefecto de Huánuco por segunda vez.

En nueva comunicación (Huánuco, 24 de diciembre de 1904), Manuel M. Flores —también constitucionalista - expresa su desazón ante Cáceres, pues esperó con ansias la llegada de Gutiérrez, pero este, dice Flores, ha preferido reunirse con los enemigos políticos, con lo que corre riesgo su propio cargo; por ello le ruega que interceda ante el presidente Pardo para que no se le remueva de su puesto de secretario. En posterior carta (Huánuco, 7 de enero de 1905), Flores insiste en lo que llama felonía de Gutiérrez, quien, según afirma, "se ha entregado en brazos de los liberales o sea de los jefes de este partido y para complacerlos más me ha exigido que renuncie el puesto de secretario de la Subprefectura a fin de poder colocar en mi lugar a un tal Ríos liberal consumado y paniaguado de los Durand".

Pocos días después de la mencionada carta, Gutiérrez (Huánuco, 10 de enero de 1905) ajeno a lo que se está diciendo de él, escribe a Cáceres para seguir pidiendo que lo ayude para ser nombrado prefecto de Huánuco.

\section{Interrupción de la comunicación}

Las cartas que custodia la Biblioteca nacional del Perú de Teodomiro Gutiérrez y que se encuentran en el Archivo Andrés A. Cáceres se interrumpen en este punto y continuarían seis años después. No sabemos si fue porque no hubo más remisión de cartas o porque las que envió se extraviaron. Pero gracias a investigaciones sabemos que entre octubre de 1906 y agosto de 1907 Gutiérrez ocupó el puesto de subprefecto de Huancayo (Rengifo, 1977). Como no podía ser de otra manera, eleva un informe sobre la situación de la capital del departamento de Junín: "Memoria de gobierno de la provincia de Huancayo que Teodomiro Gutiérrez eleva al Prefecto del departamento de Junín”. Entre sus conclusiones se pueden destacar sus propuestas de ley contra el alcoholismo, ley contra la vagancia y el odio, ley contra el abigeato, abolición de las fiestas y de las costumbres que abyectan más y más a los indios, principalmente (Contreras \& Bracamonte, 1988, pág. 24).

Gutiérrez fue identificado cada vez más con mayor claridad como un defensor acérrimo de los derechos de los indígenas. En ello tuvo papel importante la revista El Indio, de Santiago Giraldo. Por otro lado, el ambiente general de Lima, especialmente, y de sus vanguardias intelectuales era proclive a defender al indio de la explotación de la que era objeto. En ese contexto, Pedro Zulen, Dora Mayer y Joaquín Capelo fundan en 1909, y al interior del Centro Universitario, la legendaria Asociación Pro-Indígena, que tanto hizo por sensibilizar a los espíritus sobre la situación del ser andino. En su número 11, El Indio rinde homenaje a aquellos que han servido a la causa mencionada. Bajo el título "Pléyade de los defensores de la raza indígena en el 'Centro Universitario", coloca en su portada diez pequeñas fotos circulares de sendos personajes, entre los que se encuentran Víctor Andrés Belaunde, Dora Mayer, Pedro Zulen y Teodomiro Gutiérrez, entre otros (1909). En dicho número, se consigna la siguiente nota:

El señor Gutiérrez Cuevas (apoderado de indígenas de Chucuito).

Vengo a presentar mi agradecimiento y felicitaciones al 'Centro Universitario' por su interesantísima labor pro indígena y espero que ella ha de ser de trascendentales y proficuas consecuencias.

Hizo en seguida la historia del gamonalismo, y de los trabajos de la seńorita Mayer y del Director del periódico 'El Indio'. (pág. 11)

Dos ańos después (Lima, 31 de agosto de 1911), Gutiérrez se vuelve a dirigir a Cáceres para recordarle su lealtad desde los tiempos de la campaña de La Breña — que defendió denodadamente el territorio peruano- haciendo un recorrido de su vinculación con el héroe que nos resulta útil: Gutiérrez acompañó a Cáceres desde Puruhuay hasta el 27 de agosto de 1884; desde la marcha y contramarcha de Arequipa 
hasta el 19 de marzo de 1895; entonces se negó a servir a Piérola o a Romańa a pesar que le pudo traer beneficios sociales; como vice-presidente de la "Cadena Constitucional" 25 contribuyó a organizar el recibimiento que se le hizo al héroe cuando regresó de Europa; como su secretario particular trabajó en la reorganización del partido por todo el país; como subprefecto considera que su labor fue aplaudida por sus correligionarios.

Gutiérrez recuerda estos lazos por los momentos difíciles que está viviendo producto de una acusación calumniosa de la que ha salido airoso en el fuero del Ministerio de Guerra, pero, sin embargo, el general Pizarro no tiene la decisión de emitir el "decreto vindicatorio". Por ello recurre a Cáceres, con la intención de que trate de influir en el propio Presidente de la República "para que se me haga justicia".

\section{Enviado del presidente Guillermo E. Billinghurst}

En setiembre de 1912 Guillermo E. Billinghurst es designado por el Congreso como el nuevo Presidente de la República. Primera expresión de la aparición del populismo en el Perú, el gobierno del comerciante salitrero tuvo como prioridad atender las necesidades de los trabajadores obreros, artesanos y también de los indígenas. Esto explica la identificación de Gutiérrez por el político iquiqueño y que haya hecho campaña directa por él integrando el Club Billinghurista Unión Militar No. 1 en calidad de su vice-presidente. Es más, un día tan significativo como fue el 20 de mayo de 1912 —el día en el que la multitud de Lima salió a las calles para apoyar a Billinghurst en su camino a la presidencia del país-, Gutiérrez, según palabras impresas en los diarios $E l$ Comercio y La Prensa, dirigió al señor Billinghurst un entusiasta discurso apoyando su candidatura. ${ }^{26}$ En el

25 Según Iván Millones, historiador y estudioso del Partido Constitucional, la "Cadena constitucional" podría referirse a un tipo de club político del Partido Constitucional o, en su defecto, al agrupamiento (o "coalición") de varios clubes electorales afiliados a ese partido. Comunicación personal: 11 de setiembre de 2017.

26 El Comercio, 20 de mayo de 1912, Edición de la Mañana, pág. 2. "La gran manifestación popular de hoy", La Prensa, 20 de mayo de 1912, pág. 2. Véanse los muy importantes libros de Alejandro Salinas Sánchez, La época del "Pan Grande". Billinghusrt presidente. 19121914, Universidad Nacional Mayor de San Marcos, Lima, 2014, y el de Luis Torrejón, Rebeldes republicanos: la turba urbana de 1912, Red para el Desarrollo de las Ciencias Sociales en el Perú, Lima, 2010. mes de julio, junto al escritor Abraham Valdelomar, según el diario La Prensa, “...Teodomiro Gutiérrez pronunció un patriótico discurso haciendo una larga reseña de los servicios prestados a la nación por el candidato nacional señor Guillermo E. Billinghurst por quien dijo que encarnaba la más grata esperanza del país" (La Prensa, 1912, pág. 1).

Por esta razón, en 1913, enterado el presidente de los conflictos sangrientos ocurridos en Puno envía a Teodomiro Gutiérrez a Huancané y Azángaro, especialmente al distrito de Samán, para que averigüe las causas sociales de la violencia y emita un informe. ${ }^{27}$ Llegó a Juliaca entre los días 25 y 30 de setiembre y difundió un manifiesto en quechua por el que transmitía los saludos del presidente Billinghurst, y pedía a todos que quisieran hablar con él, lo hagan, con tranquilidad y sin "formar escándalos" (Ramos Zambrano, Necesitamos otro Rumi Maqui, 2011, pág. 351). A pesar de los escozores que generó en los terratenientes la comisión que comandaba Gutiérrez $y$, por tanto, las resistencias mostradas por las autoridades, el enviado especial del presidente pudo evacuar su informe. Un extracto del documento preparado por nuestro personaje es desgarrador:

Los indígenas de Samán pusieron a mi vista los cadáveres carbonizados de sus parientes y amigos, que habían sido quemados vivos, entre los cadáveres el de una muchacha, hija del indio Andrés Apaza, que antes de ser quemada viva había sido violada por esos monstruos; se me presentaron para ser examinados por mí, personalmente, varios indígenas, a quienes los gamonales los habían castrado; vi algunas casas en las estancias que esos barbaros, de ese nuevo Putumayo, al no poderse llevar todos los víveres en su riguroso saqueo, los habían mezclado con tierra y con ceniza, para que los indios fueran sumidos en el hambre y la miseria. (Gallegos, 1973, pág. 6)

Pero Billinghurst sería rápidamente depuesto de la presidencia. El 4 de febrero de 1914, la alianza civilmilitar encabezada por los hermanos Jorge, Javier y Manuel Prado Ugarteche, entraría a Palacio de la mano del coronel Óscar R. Benavides, y lo enviaría

27 En carta publicada en el diario El Pueblo de Arequipa el 20 de setiembre de 1913, Gutiérrez aseguraba que realizaría una investigación "imparcial y sin perjuicio alguno". Véase Augusto Ramos Zambrano, Ezequiel Urviola y el indigenismo puneño, Fondo Editorial del Congreso del Perú, Lima, 2016, pág. 349. 
al exilio en Chile. Por su parte, y sin respaldo político, Gutiérrez huiría, también se establecería en Chile, y regresaría al Perú en pleno ejercicio de la primera magistratura del mencionado coronel que había asumido el cargo de Presidente provisorio; establece contacto con obreros anarcosindicalistas se escribe con Francisco Chuquihuanca Ayulo (abogado indigenista) y forma un círculo importante con otros defensores del indio, como Telésforo Catacora (educador), Santiago Giraldo (abogado y periodista), Ezequiel Urviola (mestizo que dirigió rebeliones indígena), Julián Palacios (quien le sirvió como secretario) y otros. ${ }^{28}$

En el Archivo Andrés A. Cáceres se conserva una carta de ese tiempo. Gutiérrez le escribe a su protector desde Lima el 21 de agosto de 1914, es decir, seis meses después de haber sido derrocado Billinghurst, para comentarle que habiendo estando en Valparaíso se enteró de su visita a dicha ciudad, y que luego de regresar al Perú desde Chile fue a saludarlo pero sin suerte. Es necesario señalar que Gutiérrez ya firma como mayor del ejército, pero todavía no como Rumi Maqui. Augusto Ramos Zambrano (1985) ya había hecho mención a una información similar: la correspondencia de Gutiérrez con Chuquihuanka Ayulo, a quien en carta de la misma fecha de la misiva líneas arriba mencionada le dice que está preparando todo lo necesario para llevar a cabo su "proyecto"; por otro lado, se colige que reingresó al Perú legalmente.

En otras comunicaciones incide en su proyecto (que seguramente es la preparación de la rebelión indígena), le comenta sobre su propósito de editar la publicación La Voz del Pueblo y construir una catapulta (que después devendría innecesaria). El mismo Ramos Zambrano afirma categóricamente que entre los meses de agosto y setiembre, Gutiérrez se autonombró Restaurador del Imperio del Tahuantinsuyo adoptando el seudónimo de Rumi Maqui. En un documento excepcional, se constata que Gutiérrez se acredita como Restaurador del Estado Federal del Tahuantinsuyo y firma como General Rumi Maqui. Se está preparando para la guerra.

28 Es necesario señalar que desde finales del siglo XIX hasta las primeras décadas del siglo XX Puno vivió una gran efervescencia intelectual, política e ideológica. Alos mencionados habría que agregar a José Antonio Encinas (educador), los hermanos Federico y Ernesto More (periodistas), Carlos Oquendo de Amat, Gamaliel Churata y los integrantes del grupo Orkopata (literatos), entre otros.
Las reacciones fueron de variados tonos, dependiendo de quién observara los hechos: temor de los gamonales, inquietud del gobierno, expectativa de los indigenistas, esperanza de los indios. En el periodismo de la época se publicaron notas de distinto carácter, como el análisis serio de Mariátegui o la crónica jocosa de Clemente Palma. El hijo del tradicionista, bajo el seudónimo reconocido en su tiempo de Juan Apapucio Corrales, relata una supuesta entrevista "Con el Inca Rumimaqui", para la cual debió trasladarse a Juliaca con todas las dificultades que implicaba un viaje a ese lugar en los primeros años del siglo XX. Siempre utilizando un lenguaje humorístico Palma reproduce algunos entendidos sobre el personaje. En principio, que se considera Inca, que odia a los gamonales y desea regresar a los tiempos del Tahuantinsuyo. Pero, luego, que se trata de un personaje conocido en Lima, "amigazo" del cronista incluso, con el cual bebe licor y riñe por mujeres. Es decir, el cronista presenta una visión ambivalente de Rumi Maqui. Quizás el humor escondía algo de temor (Palma, 1938).

Diversos trabajos relatan muy bien los antecedentes de la violencia social que vivía Puno en setiembre de $1915 .{ }^{29}$ En la provincia de Azángaro los gamonales incurrían en abusos contra los indios, provocando los justos reclamos de estos. La pasividad del subprefecto de dicha provincia atizó el enfrentamiento. El hacendado Bernardino Arias Echenique, poder local mayor, acusaba a los indios de diversos desmanes, y entabla un enfrentamiento judicial que el juez inclina a favor de los indígenas, lo que motivó una apelación, sin suerte, de Arias Echenique. Paralelamente, Gutiérrez se acerca al anarquismo luego de estar imbuido de las ideas positivistas, ser un "amante del progreso" (Contreras \& Bracamonte, 1988, págs. 10-11), y de estar próximo a las ideas de las iglesias adventistas. Identifica con absoluta claridad al gamonalismo como la razón de la opresión del indio, así como sostiene la necesidad de una revo-

29 Véase: Gallegos, L. (1973). Un héroe del pueblo. El caballero del Altiplano, Rumi Maqui. Puno: Centro de Estudios y Reflexión del Altiplano.; Ramos Zambrano, A. (1985). Rumi Maqui. Movimientos campesinos de Azángaro. Puno: Centro de Publicaciones IIDSAUNA.; Rengifo, A. (1977). Semblanza del Mayor de Caballería, Teodomiro A. Gutierrez. Campesino. págs. 12-16, Flores Galindo, A. (2010). Buscando un Inca. Identidad y utopía en los Andes. Lima: El Comercio. Arroyo Reyes, C. (2005). Nuestros años diez: la Asociación Pro-Indigena, el levantamiento de Rumi Maqui y el incaismo modernista. Uppsala: Centro de Estudios y Trabajo "América Latina». 
lución contra esos poderes locales. Gutiérrez decide tomar acciones concretas y reúne fondos e instruye militarmente a los indios. Los gamonales "se ponen en estado de alerta".

Ya Gutiérrez ha adoptado el seudónimo que lo haría mítico: Rumi Maqui, y manifestado que quiere restaurar el Tahuantinsuyo. Nunca los gamonales habían sentido tanto temor ante los indios pero en ese momento las noticias no eran totalmente claras. La carta del sargento mayor, M. Zúñiga Bejar, a Andrés A. Cáceres, es ilustrativo de los temores de los "señores" de la zona (véase Anexo no. 6). Escrita desde el distrito de Taraco (Huancané), el 25 de noviembre de 1915, Zúñiga le informa al héroe que "se ha descubierto una gran conflagración contra el gobierno y la forma del Estado encabezado por un individuo que se titula Rumimaqui”. Inmediatamente después alude a Teodomiro Gutiérrez, quien — según afirmaestá en la organización, en la parcialidad de Muni, de más de 500 hombres "para el exterminio general de los blancos”. Se deduce — según sus palabras-, que toda esta actividad cuenta con complacencia del gobernador de Samán, del subprefecto de Azángaro y del prefecto de Puno. Según Zúñiga, las raíces de la rebelión nacen en Arequipa y Cusco, porque algunos de los rebeldes vivan a Piérola, otros a la Federación y otros "al imperio del sol", para llegar a una asombrosa conclusión: "una alianza hibrida" entre policías que desean ocupar la presidencia de la República y los que sueñan con el restablecimiento del Incanato; el trono sería ocupado por Rumi Maqui, auto-titulado "supremo Director", concluye el remitente. El Post Scriptum tiene tono de urgencia: "La organización se apresura para atacar Puno y Juliaca".

El poder gamonal hizo un frente común contra la insurrección. Intensifica su campaña con el objetivo de destruir al ya entonces peligroso Rumi Maqui. El hacendado y coronel José Angelino Lizares Alarcón financió la revista El Indio, editada en Azángaro, ${ }^{30}$ que difundía así su versión de los hechos:

30 La primera época de esta publicación inició en 1876, dirigida y financiada por el cruel hacendado y retrógrado diputado por Azángaro, José Luis Quiñónez. Luego de algunas décadas, en 1914, inicia la segunda época de El Indio, del mencionado Lizares Quińónez, cumpliendo con el papel de ser el vocero de los gamonales (José Luis Luna, "Reavivando la tradición cultural de Azángaro", http://www. revistaswanqhari.galeon.com/enlaces $1114245 . \mathrm{html})$.

Mientras que en Lima, la publicación El Indio, bajo la dirección de Santiago Giraldo — que ya hemos visto- era la tribuna de los defensores de los indígenas.
Según informaciones que tenemos, los atacantes, en esta hacienda, se han aprovicionado de elementos bélicos como son armas y municiones, con las cuales y las muchísimas que tienen, á h 4 y media a.m. del mismo día asaltaron el caserío de la Hda. San José propiedad del Sr. Bernardino Arias Echenique, en donde sorprendieron á los siguientes empleados don Ricardo P. Ch. Zea, Moises Barreda, Elías Torres, G. Bustinza y Pablo Medrano, los cuales en circunstancia de defensa propia y defensa de los intereses del principal, hicieron uso de sus armas habiendo conseguido dar una lección á los atacantes, los cuales dejaron en el campo de combate 19 muertos y muchísimos heridos entre los que se cuentan don Julian Palacios (a) Apasa, secretario, intérprete y cómplice por muchos delitos del criminal Rumi Maqui, y también José María Turpo, principal cabecilla de la sublevación. (Sublevación de indios - ataques á varias haciendas - muertos y heridos - actitud de las autoridades - otros detalles - portada, 1915)

Posteriormente, informa que "S.E, el Presidente de la República ha ordenado que los delictuosos asuntos estos sean del conocimiento del fuero militar". En efecto, la amenaza que representa Rumi Maqui se tradujo, en los hechos, en el apoyo que recibieron los poderes locales mediante la pronta presencia en Puno de las fuerzas del gobierno central, entonces encabezado por el civilista José Pardo, quien ejercía su segundo periodo (1915-1919). Su espíritu modernizante mostrado en su primera gestión (1904-1908) se contrajo ante el peligro que acechaba al orden. La respuesta de Rumi Maqui fue atacar la hacienda San José, de Arias Echenique, el 10 de diciembre de 1915. Pero las fuerzas del orden llegan y vencen a los levantados, es una matanza, se llegan a contar 20 cadáveres. El poder gamonal saldría victorioso con la fuerza, no con la ley.

Hacia fines de abril de 1916, en Arequipa un grupo de gamonales asalta la casa de Gutiérrez y lo recluye en la cárcel. Hubo reacciones encontradas. En la revista Variedades (1916, pág. 624) apareció una nota que da cuenta del arresto de Rumi Maqui en un tono burlón, seguramente escrito por su director Clemente Palma (ver imagen).

Más dura es la redacción de El Indio (1916) de Azángaro, en la que vincula la insurrección de Rumi Maqui con la de Juan Bustamante casi medio siglo antes: 


\section{EL GENERAL RUMIMAQUI EN DESGRAC A}

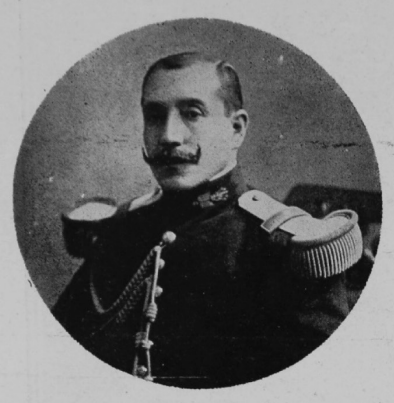

Sargento mayor Teodomiro Gutiérrez (á) ción imperialista indígena
E1 prefecto de Arequipa, por solicitud
del prefecto de Puno, ha capturado en del prefecto de Puno, ha capturado en Gutiérrez, sindicado de ser el autor de un formidable levantamiento de indigenas del departamento de Puno con el objeto de hader la restauración del imperio del Tahuantisuyo. Como se recordará, el mayor Gutierrez tomo el nombre de guerra ó cosa así) y se puso al servicio de la causa neo incaica con fe en que pronto nuestro padre el Sol alunibraría de salvajes un gran imperio, en el peor de los casos menos salvec que ia republica de cue tenemos el honor de ser citia $\mathrm{nnos.}$ mimaqui á la zona militar acusándole de traición á la patria, severidad que en verdad tie:ie visos grotescos. Bellaqueria irismo eso de la restauración del Tahuantisuyo, no merece el gesto trágico que se ha adoptado y es de esperar que la zona ción á la patria.

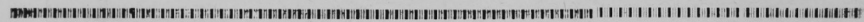

...nosotros esperábamos por momentos la noticia de que Rumimaqui había perecido como el desgraciado instigador don Juan Bustamante, en manos de los mismos indios y deudos que lo lincharon en el pueblo de Pusi, en la recordada sublevación de 1867, la muerte que le dieron fue horrorosa, las viudas y huérfanos se encargaron de acribillarlo á topazoz y agujazos, y los ancianos y niños en arrastrarlo y descuartizarlo, esto merecía Rumimaqui y no estar ahora en cómoda prisión, comiendo y durmiendo á pierna suelta y riéndose de su salvaje obra, después de haber puesto los pelos en punta á todos los pacíficos habitantes de estas regiones.

En una nueva entrega, El Indio afirma: "Ese jefe es hoy sin duda ninguna, la vergüenza de nuestro ejército y la humillación de los civiles", pues Rumi Maqui había sido acusado de traición a la patria (1916).

Por su parte, Dora Mayer se interroga por qué el apresamiento del líder de los indígenas de Puno ocurre justo cuando se ha producido un cambio en la subprefectura de Azángaro. Al parecer, desliza la idea de que el nuevo subprefecto era amigo de Arias Echenique. Mayer no defiende a Gutiérrez, pero sí intenta dar una explicación política a la situación. ${ }^{31}$

31 El propio Rengifo llama la atención en que Mayer siempre fue hostil para Gutiérrez, no así esta para con la escritora. Quizás parte de la nula simpatía que le profesaba Mayer se explique en cartas como la que le envió Apolinario Calderón desde Puno, el 3 de julio de 1912 (Archivo Pedro S. Zulen, Biblioteca Nacional del Perú), en la que le suplica que le haga el servicio de averiguar la dirección de Gutiérrez, pues, dice, que se ha llevado a sus hijos "Daniel u Marcelino Claros" hace algunos años (seguramente los enroló en sus filas) y no sabe si están vivos o muertos, "y yo pobre infeliz estoy padeciendo aquí ni a quien apoyar me haga el favor de averiguarlo de todos modos".
El gran líder arequipeño, el liberal Francisco Mostajo (delegado de la Pro Indígena en dicha provincia) exigió su libertad presentando un recurso legal. Pero el Ministerio de Guerra decidió abrirle juicio militar al levantisco por traición a la patria. Entonces Mostajo desiste de continuar defendiéndolo, pues sospechaba que Gutiérrez se aprovechó de la "credulidad de los indígenas". Este asume su propia defensa mediante carta a El Comercio de Lima y un reportaje en El Pueblo de Arequipa. Ataca con dureza al gamonalismo, acusa en vez de defenderse y logra llamar la atención sobre su situación, incluso en el Parlamento. Mientras tanto, en la cárcel realiza labor proselitista y enseña a los soldados a tener comprensión con la situación del indígena. Se hace amigo de sus custodios y el 1 de enero de 1917, aprovechando las fiestas de Año Nuevo, Rumi Maqui escapa de la cárcel, luego de estar ocho meses preso. A fines de ese mes, El Pueblo publica una carta suya ratificando las razones de su lucha. Al parecer, llegó a Bolivia (luego de pasar por la hacienda Anccoyo de Sandia, a la que incendió junto a Tomás Condori y un grupo de indios). Al día siguiente, José Carlos Mariátegui (1992) escribiría que Rumi Maqui "Anda a salto de mata", y que "acongoja una zozobra que es la zozobra del león suelto” (págs. 171-172). Después no se supo más de él, aunque Ramos Zambarno ha sostenido que Gutiérrez murió en Potosí en el año 1937. ${ }^{32}$ Además, ha afirmado que solicitó al presidente Luis M. Sánchez Cerro pensión de jubilación por su servicio militar, solicitud que fue concedida.

Ramos Zambrano (2011) agrega más datos: "Él [Rumi Maqui] había ido a Puerto Maldonado, desde Bolivia, para dar Poder a su esposa y ella, en Lima, cobraba la pensión. Incluso, después de que murió Rumi Maqui todavía la esposa viuda, seguía cobrando esa pensión; de tal manera que eso es cierto". Si esa información es cierta, la hipótesis sostenida por Alberto Flores Galindo (2010), de que el seudónimo Rumi Maqui sirvió para identificar a varios líderes rebeldes (págs. 209-2015), debe ser descartada, Lo que no es refutable es que luego de huir nunca

32 Ramos Zambrano asegura que: "Su partida de defunción pasó por mis manos. Falleció, según se dice, con una neumonía ya bastante avanzada a una edad muy avanzada". En: http://www.losandes.com. pe/Sociedad/20110313/47330.html 
más se tuvo noticias de Teodomiro Gutiérrez/Rumi Maqui. $^{33}$

Como dice una nota publicada en El Comercio (también cercano a los poderes regionales) que reproduce El Indio de Azángaro:

La huella de Rumi-maqui se perdió; anduvo tal vez extraviado en las punas: viviendo á saldo de mata, sin amparo y sin refugio. En el camino á Arequipa lo encontró el nuevo prefecto de Puno, don Carlos Zapata: iba Rumi-maqui abandonado de sus súbditos, ocultándose, tratando de buscar una salida fuera del país que había querido desmembrar. Ya nada tenía de su esplendor pasado. El emperador omnipotente era ya sólo el mayor Teodomiro Gutiérrez Cuevas. (El Enjuiciamiento de Rumimaqui., 1916)

\section{Rumi Maqui en la bruma de la historia}

Gutiérrez, sargento mayor de caballería del ejército peruano, tuvo una sensibilidad especial frente al tema indígena, de otro modo, no hubiera pertenecido a la Pro-Indígena. Como subprefecto en diversas zonas y como emisario del gobierno de Guillermo E. Billinghurst, Gutiérrez conoció de cerca la situación de explotación y extrema crueldad que caracterizaba la relación del gamonal con el campesino de la sierra. El gamonalismo llega a ser identificado por Gutiérrez como el personaje central de la dominación contra el indio, ubicado en el vértice de un sistema diseñado para ejercer la expoliación del ser andino. Este, concebido por los gamonales casi al nivel de los animales de carga, era sometido a largas y duras jornadas de trabajo, en donde muchas veces dejaba hasta su propia vida sin llegar a ser nunca dueño de su voluntad.

33 En documentación recuperada por Ramos Zambrano en el texto Rumi Maqui. Movimientos campesinos de Azángaro. Puno: Centro de Publicaciones IIDSA-UNA. (págs. 62-70), se encuentra la descripción de su gran proyecto: La Gran Confederación Sudamericana del Pacífico. Se trata de un Programa de 18 puntos. En el punto 16 dice textualmente: "Los doctores Santiago Giraldo, Francisco Chukiwanca Ayulo, la señorita Dora Mayer, dos seńoras o señoritas más, del Perú o de Bolivia, y algunos bolivianos afectos a nuestra causa, en número de diez cuando menos, integrarán el gobierno de la Revolución". Véase Ramos Zambrano. (2016). Ezequiel Urviola y el indigenismo puneño, 2016, pág. 412.

\section{El militar y el indio}

La comprensión que mostraba Gutiérrez frente a la situación indígena era poco común entre los militares de su tiempo, generalmente guardianes de los poderes económicos y políticos. Pero al mismo tiempo, Gutiérrez no es el único militar que adopta posiciones pro-indígenas. En este sentido, Cecilia Méndez (2006) advierte que antes que él existió Juan Bustamante, también militar, coronel del ejército, que denunció los maltratos contra los indios:

...no se ha reflexionado suficientemente sobre el origen militar de estos personajes. No creo que se trate de meras coincidencias. Nos atrevemos a afirmar, más aún, que el indigenismo del coronel Bustamante puede haber influido de manera directa en el pensamiento liberal de comienzos del siglo XX, específicamente en las ideas de uno de los más acérrimos críticos de la política peruana y el militarismo, Manuel Gonzáles Prada. Su célebre frase 'no forman el verdadero Perú las agrupaciones de criollos y extranjeros que habitan en la faja de la tierra situada entre el Pacífico y los Andes; la nación está formada por las muchedumbres de indios diseminados en la banda oriental de la cordillera', parece una paráfrasis de un texto de Juan Bustamante. (pág. 15)

En este tenor, Antonio Zapata (2015) encuentra continuidad entre Rumi Maqui y otro militar, Juan Velasco Alvarado, quien llevó a cabo una serie de reformas anti-oligárquicas durante los años 1969 y 1975. Y siguiendo esta perspectiva de análisis podríamos extendernos hasta nuestros años y el denominado etno-cacerismo, que parece una reivindicación de Rumi Maqui. Tiene razón Méndez en el sentido de que es necesario reflexionar sobre este tema.

\section{El rebelde y los gamonales}

El temor y desagrado con que vieron las élites oligarcas el papel de Gutiérrez se acrecentaba en la medida que el gobierno que lo había enviado a su misión en la sierra fue el de Billinghurst, que había definido una clara política de distanciamiento con los poderes tradicionales. Billinghurst y Gutiérrez son dos personajes que anunciaron con claridad la crisis política que enfrentaría el Perú pocos años después, producto 
de la recomposición en el dominio oligárquico y su alianza con el militarismo, el ingreso de la plebe a los predios de la política, y la aparición de los partidos populares y radicales.

Como hemos visto, Gutiérrez conoció de cerca la realidad indígena, gracias tanto a su función de militar (especialmente en los tiempos de la Guerra con Chile junto a Andrés A. Cáceres), como por su desempeño como subprefecto en diferentes lugares del Perú. En el departamento de Puno, los señores de horca y cuchillo, dueños de hombres y tierras, encarnaron con mayor fidelidad al gamonal. Y fue precisamente por su extremo dominio que generó los mayores levantamientos de campesinos y, por supuesto, las más violentas represiones y matanzas. Luego de que Rumi Maqui huyera del país y de una serie de sucesos poco claros (su apresamiento, fuga y nebulosa forma de desaparecer), ${ }^{34}$ Rumi Maqui, como afirma Carlos Arroyo Reyes (2005), pasó a ser parte del mito, del imaginario colectivo, más aún cuando pocos años después se produjera la gran ola de levantamientos campesinos en el Sur andino. En ella, el recuerdo de Rumi Maqui siempre estuvo presente.

\section{Líneas finales}

Las páginas de esta pequeña entrega nos ofrecen información desconocida sobre el personaje Teodomiro Gutiérrez/Rumi Maqui, fundamentalmente gracias al análisis que ha sido posible realizar de las cartas que este envió a El Brujo de los Andes, el general Andrés A. Cáceres, defensor del territorio nacional hasta más allá de los límites de las fuerzas y posibilidades durante la nefasta Guerra del Pacífico. Son cartas que ya no dejan lugar a dudas sobre la relación que existió entre Gutiérrez y Cáceres. Ello confirma la importancia que tiene la correspondencia personal para el análisis social, cultural y político, en tanto fuente de datos e información a la que de otro modo es imposible acceder. Asimismo, su contenido nos revela las vicisitudes cotidianas de nuestro personaje productos de su relación — de oposición y fuerza- con los poderes

34 En esto guarda similitud con Juan Santos Atahualpa quien también desapareció misteriosamente hacia el ańo 1756, luego de dirigir una gran rebelión indígena en el ańo 1742 en la zona del Gran Pajonal, con el propósito de restaurar el Tahuantinsuyo y expulsar a españoles y negros. No se supo más de él. locales, los terratenientes, es decir, el poder gamonal, especialmente en Puno. Desde esa relación específica se nos revela toda la estructura social de dominación que prevalecía en los Andes peruanos en las primeras décadas del siglo XX, así como parte de los debates ideológicos y del proceso político. Sin embargo, continúa siendo Rumi Maqui un personaje que merece ser estudiado con la esperanza de encontrar nueva documentación que nos permita ir llenando vacíos en nuestra información y redondear una imagen del gran rebelde que fue Teodomiro Gutiérrez, quien luchó contra las injusticias y abusos que los llamados "señores" cometían diaria e impunemente contra los habitantes andinos.

\section{Fuentes consultadas}

\section{Libros}

Discursos del H. Diputado por Huancané Dr. D. Santiago Giraldo. Legislatura de 1900. (1900). Lima: Imprenta y Encuadernación Víctor A. Torres.

Giraldo, S. (Ed.). (1903). La raza indigena en los albores del siglo XX. Lima: Imprenta de Víctor A. Torres.

Palma, C. (1938). Con el Inca Rumi Maqui. En C. Palma, Crónicas político-doméstico-taurinas (págs. 132-136). Lima: Compañía de Impresiones y Publicidad.

\section{Publicaciones oficiales}

Escalafón general del Ejército y la Armada. (1899). Lima: Imprenta Torres Aguirre.

Escalafón general del Ejército. Publicación Oficial. (1908). Lima: Imprenta El Lucero.

Escalafones de actividad, disponibilidad y retiro. (1915). Lima: Imprenta del Servicio Geográfico del Ejército .

Escalafones de actividad, disponibilidad y retiro. (1916). Lima: Imprenta del Estado Mayor General del Ejército.

Estado Mayor General del Ejército . (1913). Escalafón general del Ejército. Primera parte. Disponibilidad Grupos Ay $B$. Lima: Imprenta del Servicio Geográfico del Ejército.

Estado Mayor General del Ejército. (1914). Escalafón general del Ejército. Primera parte. Disponibilidad Grupos Ay $B$. Lima: Imprenta del Servicio Geográfico del Ejército.

Ministerio de Guerra y Marina. (1904). Escalafón general del Ejército. Publicación Oficial. Lima: Imp. Torres Aguirre. 
Ministerio de Guerra y Marina. (1907). Escalafón del Ejército. Publicación oficial. Lima: Tipografía El Lucero.

Ministerio de Guerra y Marina. (1910). Escalafón de las listas pasivas. Publicación oficial. Lima: Tipografía Unión Boza.

Ministerio de Guerra y Marina. (1909). Escalafón general del Ejército. Publicación Oficial. Lima: Escuela Militar.

\section{Publicaciones seriadas}

(2 de Agosto de 1884). El Comercio.

(1904). El Indio. Defensor de los intereses sociales de la raza indigena (3), 3.

(28 de Julio de 1909). El Indio. Defensor de los intereses sociales de la raza indígena (11).

(2 de Julio de 1912). La Prensa, pág. 1.

El Enjuiciamiento de Rumimaqui. (27 de mayo de 1916). El Indio. Segunda época. Decenario político, noticioso y comercial (62).

El general Rumimaqui en desgrac[i]a. (13 de Mayo de 1916). Variedades (428), 624.

El Indio. (27 de Agosto de 1904). El Indio. Defensor de los intereses sociales de la raza indigena (3), 1.

González Prada, M. (1904). Autoridad Humana. El Indio. Defensor de los intereses sociales de la raza indígena (3), 2.

Gutiérrez Cuevas. (1916). El Indio. Segunda época. Decenario político, noticioso y comercial (62).

Gutiérrez, T. (1904). Manifiesto del Sub-Prefecto de la Provincia de Chucuito a los pueblos de su mando. El Indio. Defensor de los intereses sociales de la raza indígena (2), 7.

Gutiérrez, T., \& Estrada Luna, D. (1904). Bando de Teodomiro Gutiérrez, subprefecto de la Provincia de Chucuito. El Indio. Defensor de los intereses sociales de la raza indigena (2), 6.

Quintana, J. (1904). Decreto Supremo comisionando a José Cavero Ovalle. El Indio. (2), 6.

Ráez, N. (7 de marzo de 1903). Nota. El Huallaga(14).

Rumimaqui. (3 de Mayo de 1916). El Indio. Segunda época. Decenario politico, noticioso y comercial (52).

Sublevación de indios - ataques á varias haciendas - muertos y heridos - actitud de las autoridades - otros detalles portada. (18 de Diciembre de 1915). El Indio. Segunda época. Decenario político, noticioso y comercial (52).

\section{Bibliografía}

Arroyo Reyes, C. (2005). Nuestros años diez: la Asociación Pro-Indígena, el levantamiento de Rumi Maqui y el incaísmo modernista. Uppsala: Centro de Estudios y Trabajo "América Latina».

Bustamante, L. (1987). Mito y realidad: Teodomiro Gutiérrez Cuevas o Rumi Maqui en el marco de la sublevación campesina de Azángaro. Lima: Pontificia Universidad Católica del Perú.

Castro Lizarbe, R. (2014). Cáceres, Prefecto del Cuzco. Documentos inéditos (1877-1878). Lima: Orden de la Legión Mariscal Cáceres.

Charaja, M., \& Huanca, M. (1904). Memoriales. El Subprefecto de Chucuito. El Indio. Defensor de los intereses sociales de la raza indígena(3), 6 .

Contreras, C., \& Bracamonte, J. (1988). Rumi Maqui en la Sierra Central. Lima: Instituto de Estudios Peruanos.

De la Puente Candamo, J. A., \& De la Puente Brunke, J. (Edits.). (2008). El Perú desde la intimidad. Epistolario de Manuel Candamo (1873-1904). Lima: Pontificia Universidad Católica del Perú.

Flores Galindo, A. (2010). Buscando un Inca. Identidad y utopia en los Andes. Lima: El Comercio.

Gallegos, L. (1973). Un héroe del pueblo. El caballero del Altiplano, Rumi Maqui. Puno: Centro de Estudios y Reflexión del Altiplano.

Giraldo, S. (1944). Legislación militar. Crítica Parlamentaria por el H. Diputado. Lima: Imprenta Portal de San Agustín No 44.

Löwy, M. (1978). Para una sociología de los intelectuales revolucionarios: la evolución politica de Lukács, 19091929. México: Siglo Veintiuno editores.

Málaga Sabogal, X. (2014). La educación racializada: politicas educativas para indigenas a inicios del siglo XX. (Tesis de Maestría). Pontificia Universidad Católica del Perú, Lima.

Manrique, N. (1981). Las guerrillas indígenas en la Guerra con Chile. Lima: Centro de Investigaciones y Capacitación.

Marí́tegui, J. C. (1992). Grimas y Zozobras. El Tiempo. Lima 17 de enero de 1917. En J. C. Mariátegui, Escritos juveniles (La Edad de Piedra) (Vol. IV, págs. 171-172). Lima: Biblioteca Amauta. 
Melgar BaO, R. (2014). El epistolario como vehículo de comunicación y cultura: México en las cartas de José Carlos Mariátegui. Pacarina del Sur(18). Recuperado de www.pacarinadelsur.comindex.php?option=com_cont ent $\&$ view $=$ article $\&$ id $=914 \&$ catid $=46$.

Mendez, C. (2006). Las paradojas del autoritarismo: ejército, campesinado y etnicidad en el Perú, siglo XIX al XX. Iconos. Revista de Ciencias Sociales(26), 15.

Millones Maríñez, I. (2004). Los caceristas de la República Aristocrática: composición social, intereses y principios del Partido Constituciona (1895-1919)l. Histórica, XXVIII(2).

Ramos Zambrano, A. (1985). Rumi Maqui. Movimientos campesinos de Azángaro. Puno: Centro de Publicaciones IIDSA-UNA.

Ramos Zambrano, A. (13 de Marzo de 2011). Necesitamos otro Rumi Maqui. (M. Mayhua Quispe, Entrevistador). Recuperado de http://www.losandes.com.pe/ Sociedad/20110313/47330.html
Ramos Zambrano, A. (2016). Ezequiel Urviola y el indigenismo puneño. Lima: Fondo Editorial del Congreso del Perú.

Rengifo, A. (1977). Semblanza del Mayor de Caballería, Teodomiro A. Gutierrez. Campesino.

Salinas Sánchez, A. (2014). La época del "Pan Grande». Billinghust presidente 1912-1914. Lima: Universidad Nacional Mayor de San Marcos.

Torrejón, L. (2010). Rebeldes republicanos: la turba urbana de 1912. Lima: Red para el Desarrollo de las Ciencias Sociales en el Perú .

Velásquez Silva, D. V. (2013). La reforma militar y el gobierno de Nicolás de Piérola. El Ejército moderno y la construcción del Estado Peruano (Tesis de Magíster). Universidad Nacional Mayor de San Marcos, Lima.

Zapata, A. (4 de noviembre de 2015). Rumi Maqui: un héroe popular. La República. 